\title{
O Conceito de Esperança (Hoffnung) na Filosofia de Hegel
}

\author{
[THE CONCEPT OF HOPE (HoFFNUNG) IN HEGEL'S PHILOSOPHY]
}

\section{Paulo Konzen * \\ Universidade Federal de Rondônia, Brasil}

Resumo: O objetivo é expor e analisar o conceito de "esperança" (Hoffnung) na Filosofia de Hegel, em relação ainda com os seus conceitos de "desesperança" (Hoffnungslosigkeit), de "temor" (Furcht), de "desespero" (Verzweiflung) e de "suicídio" (Selbsttötung - Selbstmord). São conceitos e problemas que nos inquietam e sobre os quais existem poucas pesquisas, além de serem atuais diante do momento histórico (2020) de pandemia, de tanta doença ou de falta de saúde. Trata-se de pesquisa, exposição e análise crítica-filológica, histórica e hermenêutica da obra de Hegel, nos fundamentando em textos clássicos e interpretativos, buscando devidamente apreender os conceitos citados. Com isso, em suma, se procura citar e compreender, de forma apropriada, o pensamento hegeliano, examinando a sua obra diante das reais circunstâncias em que foi exposta, evitando as muitas exposições e interpretações equivocadas, pois há uma disputa, a princípio, entre o que Hegel disse e o que dizem que ele disse e/ou do que deveria ou poderia ter dito. Em resumo, o principal objetivo é expor e analisar, de forma criteriosa, o que Hegel realmente afirmou e, por isso, o trabalho propositadamente possuirá muitas citações, notas e aspas.

Palavras-ChaVe: Hegel; Filosofia; esperança; desesperança; temor; desespero; suicídio
ABstract: The objective is to expose and analyze the concept of "hope" (Hoffnung) in Hegel's Philosophy, in relation to his concepts of "hopelessness" (Hoffnungslosigkeit), "fear" (Furcht), "despair" (Verzweiflung) and "suicide" (Selbsttötung - Selbstmord). These are concepts and problems that concern us and about which there is little research, besides being current in the face of the historical moment (2020) of a pandemic, of so much illness or of lack of health. They are research, exposure and critical-philological, historical and hermeneutic analysis of Hegel's work, based on classical and interpretative texts, seeking to properly understand the concepts cited. With this, in short, we try to quote and understand, in an appropriate way, the Hegelian thought, examining his work before the real circumstances in which it was exposed, avoiding the many expositions and misinterpretations, because there is a dispute, at first, between what Hegel said and what they say he said and/or what he should or could have said. In summary, the main objective is to expose and analyze, in a judicious way, what Hegel really said and, therefore, the work will purposefully have many quotations, notes and quotes.

KEYwords: Hegel; Philosophy; hope; hopelessness; fear; despair; suicide

\section{INTRODUÇÃo}

artigo é uma pesquisa, exposição e análise crítica-filológica, histórica e hermenêutica $^{1}$ da obra de Hegel, nos fundamentando em textos clássicos e interpretativos, buscando assim apreender devidamente o conceito de "esperança" (Hoffnung), exposto e analisado na sua Filosofia, em relação ainda com os seus conceitos de "desesperança" (Hoffnungslosigkeit), de "temor" (Furcht), de "Verzweiflung" (desespero) e de "suicídio"

* Doutor em Filosofia Universidade Federal do Rio Grande do Sul, UFRGS. Professor de Filosofia no Departamento de Filosofia e no Programa de Pós-Graduação em Filosofia da Universidade Federal de Rondônia,UNIR.E-mail: prkonzen@unir.br 
(Selbsttötung - Selbstmord). Em suma, o objetivo é citar e compreender, de forma apropriada, o pensamento hegeliano, examinando a sua obra diante das reais circunstâncias em que foi exposta, evitando as muitas exposições e interpretações equivocadas, pois há uma disputa entre o que Hegel disse ${ }^{2}$ e o que dizem que ele disse e/ou do que deveria ou poderia ter dito. Em suma, o objetivo principal do estudo é expor e analisar, de forma criteriosa, o que Hegel realmente afirmou e, por isso, o presente trabalho possuirá propositadamente muitas citações, notas e aspas.

\section{A IMPORTÂNCIA do CONCEITO de ESPERANÇA E A FILOSOFIA}

Inicialmente, falar de esperança é algo importante e essencial, porque a falta de esperança ou a desesperança, o perder a esperança, a pouca esperança, o estar sem esperança, a esperança vazia, a esperança banal, a esperança falha, a esperança fracassada, a esperança infundada, a esperança vaga, a esperanças fútil, a esperança iludida ou enganada (versus alegada esperança crítica, esperança viva, esperança verdadeira, etc.), entre outros, com o perdão do jogo de palavras, inviabiliza ou influencia a esperança de um futuro melhor ou mesmo de um mundo de esperanças. Em suma, como veremos, Hegel menciona todos esses termos.

Mas, convém registrar que Hegel não é um filósofo que faz da "esperança" (Hoffnung) o "princípio fundamental de sua filosofia", tal como Ernst Bloch (1885-1977)³, talvez nem mesmo se for sob o aspecto de uma "esperança pela liberdade"4 (Hoffnung zu... Freiheit). Ora, sobre isso, tanto na obra The Hegel Dictionary, de Glenn Alexander Magee, quanto na obra $\mathrm{A} \mathrm{Hegel}$ Dictionary [Dicionário Hegel], de Michael Inwood, não há um verbete para "esperança" (hope); no máximo, ao falar sobre o uso do seu dicionário, Inwood (1997, p. 35) afirma:

[...] para apreciar inteiramente a influência de Hegel, nós precisamos entender o próprio Hegel [we need to understand Hegel himself]. E para isso precisamos, entre outras coisas, conhecer algo das complexidades de sua linguagem. Assim, neste Dicionário, digo relativamente pouco acerca dos pensadores que influenciaram Hegel ou sobre a história posterior dos termos que ele usou, e muito mais a respeito de pensadores (alemães e nãoalemães) que ajudaram a moldar sua linguagem e conceitos, e sobre o seu próprio e criativo uso do que herdou deles. Hegel sugeriu que as últimas obras de Platão deviam ser prefaciadas pelas palavras que Dante colocou acima da entrada para o Inferno: "Abandonai toda a esperança, vós que entrais aqui!" ['Abandon all hope, you who enter here!'] Hegel não pretendeu dizer que não deveríamos ler essas obras: seu valor filosófico é, a seu ver, proporcional à sua dificuldade [difficulty]. As obras de Hegel são igualmente difíceis [Hegel's works are similarly difficult]. Mas este livro foi escrito na crença de que o leitor não precisa abandonar toda a esperança de compreendê-las [But this book is written in the belief that the reader need not abandon all hope of understanding them] e pode, tal como Dante, reemergir delas enriquecido.

Novamente pedindo perdão pelo jogo de palavras, convém não perder ou abandonar toda a esperança de entender ou compreender o que Hegel expõe sobre o conceito de esperança. Ora, Inwood (1997, p. 66-67) indiretamente oferece um aspecto essencial, ao falar do ceticismo:

Hegel distingue o ceticismo [Skeptizismus] da dúvida (especialmente cartesiana). Zweifel ("dúvida") provém de zwei ("dois") e subentende um continuado apego às crenças de que se duvida e uma esperança [a hope] de recuperação da confiança nelas. A dúvida cética é, antes, desespero [despair] (Verzweiflung), um abandono irremediável [ou sem esperança] [hopeless abandonment] da posição posta em dúvida.

Sobre isso, no $\S 81 \mathrm{Z}$ (2015a, p. 166 [TN] [8/175-176]) da Enciclopédia, consta:

O ceticismo não pode ser considerado simplesmente como uma doutrina-da-dúvida [Zweifelslehre]; ele está, antes [vielmehr], absolutamente certo [schlechthin gewiß] de sua Coisa, isto é, da nulidade de todo o finito. Quem apenas duvida está ainda na esperança de que sua dúvida poderá ser resolvida [Wer nur zweifelt, der steht noch in der Hoffnung, daß sein Zweifel gelöst werden könne], e que uma ou outra das determinações entre as quais oscila se mostrará como algo firme e verdadeiro [Festes und Wahrhaftes]. Ao contrário, o ceticismo é propriamente [eigentliche] o desespero rematado [die vollkommene Verzweiflung] de tudo [an allem] o que há de firme no entendimento, e a disposição 
espiritual [Gesinnung] daí resultante é o da imperturbabilidade e do repousar em si mesmo.

Em Hegel, um dos aspectos principais para apreender ou compreender o seu conceito de "esperança" (Hoffnung) ${ }^{5}$ é, segundo veremos, o conceito de "desespero" (Verzweiflung) ${ }^{6}$, pois significa, no caso, "desesperança" (Hoffnungslosigkeit) ou "perder a esperança" (die Hoffnung verlieren), podendo levar ao "desespero rematado [ou total]" (vollkommene Verzweiflung) ou, até mesmo, levar alguém a ficar "totalmente desesperado" ou em "desespero completo" (Verzweiflungsvolle), que pode levar, segundo Hegel, a "um impulso irresistível ao suicídio" (ein unbezwingbarer Trieb zum Selbstmord). Trata-se de aspecto importante e atual.

Sobre isso, convém citar Paulo Meneses (2000, p. 113-122), um dos principais tradutores de Hegel no Brasil, o qual, ao escrever artigo intitulado "Os horizontes da esperança", afirma:

\begin{abstract}
Hegel era inimigo declarado do pensamento utópico. [...] os filósofos têm de debruçar-se sobre eles [os sinais dos tempos], pois têm como tarefa traduzir seu tempo em conceitos. Hegel tem um aforismo famoso: "Não podes ser melhor do que teu tempo, mas podes ser o melhor de teu tempo". Trata-se de rememorar a trajetória de seu tempo, de captar-lhe o sentido, e de vislumbrar assim os rumos do porvir, partindo dos novos germes que estão brotando no presente. [...] É muito fácil elencar defeitos, distorções, perigos e ameaças trágicas de nossa época. Mais difícil é encontrar quem se aplique a detectar os sinais de esperança. A esperança é uma força dialética do espírito humano [...] e assim a esperança abre caminho por onde se parecia ter chegado ao desespero extremo. [...] Recapitulando o que foi dito, o horizonte de nossa esperança é povoado não de sonhos [...] [pois precisa ter] base à nossa esperança [...]. Assim, [...] prenunciem uma sociedade em que a vida vença a morte, a paz supere a guerra: um mundo novo que não soçobre na catástrofe e desespero, mas que assista ao triunfo - sofrido mas certo - da esperança. [...] são esses pontos germinativos do futuro que Hegel descortinava; são os vislumbres que surgem e se expandem nos horizontes de nossa esperança.
\end{abstract}

O autor, no citado artigo, procura fazer uma "ponte" entre "o pensamento de Hegel e o de [Henri] Bergson [1859-1941]" para falar sobre o "horizonte de nossa esperança", mas não cita e analisa nesse artigo passagens hegelianas sobre a esperança. Ora, já no presente artigo, procuraremos o máximo possível apresentar e examinar as principais ocorrências do conceito de esperança (Hoffnung) na Filosofia ou na Obra de Hegel (Hegel Werke).

\title{
3. Os Conceitos de esperança na Filosofia ou na Obra de Hegel (Hegel WERKE)
}

Inicialmente, convém registrar que o número de vezes que ocorre o termo "esperança" (Hoffnung) na Filosofia ou na Obra de Hegel (Hegel Werke) é grande, mas muitas delas sem grande relevância do ponto de vista conceitual, não apresentando uma análise crítico-filológica e/ou hermenêutica. Assim, buscaremos apresentar e analisar as ocorrências mais relevantes, a partir das quatro obras principais publicadas em vida por Hegel, a saber: Fenomenologia do Espírito (1807), Ciência da Lógica (1812 e 1816), Enciclopédia das Ciências Filosóficas (1817, 1827 e 1830) e Filosofia do Direito (1820-1821). Mas, também, procuraremos analisar as ocorrências principais nos demais textos da Hegel Werke, isto é, nos Primeiros Escritos - volume 1, que são textos de Bern (1793-1796) e de Frankfurt (1797-1800); nos Escritos de Iena (18011807) - volume 2; nos Escritos de Nuremberg e de Heidelberg (1808-1817) - volume 4; nos Escritos de Berlim (1818-1831) - volume 11; nas Lições sobre a Filosofia da História - volume 12; nas Lições sobre a Estética - volumes 13, 14 e 15; nas Lições sobre a Filosofia da Religião volumes 16 e 17; e também nas Lições sobre a História da Filosofia - volumes 18, 19 e 20. Trata-se de conteúdo amplo e importante.

Além disso, cabe notar que as principais ocorrências de "esperança(s) [Hoffnung(en)]" e de "desesperança [Hoffnungslosigkeit]" se dão em relação com alguns conceitos e/ou adjetivos e, por isso, iremos expor e examinar o conteúdo, seguindo a ordem abaixo.

\subsection{Relação de esperança (Hoffnung) e de esperar (hoffen) em Hegel}


O uso hegeliano de "esperança(s) [Hoffnung(en)]" nem sempre é devidamente claro ou esclarecedor, muitas vezes não apresentando uma devida definição conceitual. Isso parece ser o caso, por exemplo, de uma das primeiras ocorrências do termo na Fenomenologia do Espírito (2003, p. 162 [TN] [3/166-167]), em que consta o seguinte:

[...] através da figuração do Imutável [Gestaltung des Unwandelbaren], o momento do além [das Moment des Jenseits] não apenas permanece [geblieben], porém antes ainda se reforça [befestigt]; pois, se pela figura [Gestalt] da efetividade singular parece de um lado achegarse mais à consciência singular, de outro lado está frente a ela como um uno sensível opaco, com toda a rigidez de um efetivo; a esperança de tornar-se um com ele precisa permanecer na esperança, isto é, sem cumprimento e sem presença [die Hoffnung, mit ihm eins zu werden, muß Hoffnung, d. h. ohne Erfüllung und Gegenwart bleiben]; pois, entre ela [esperança] e seu cumprimento [zwischen ihr und der Erfüllung] se interpõe, precisamente, a contingência absoluta [die absolute Zufälligkeit] ou a indiferença imóvel [unbewegliche Gleichgültigkeit] que reside na figuração mesma que fundamenta a esperança [dem Begründenden der Hoffnung]. Pela natureza do uno essente, pela efetividade de que se revestiu, ocorre necessariamente [geschieht es notwendig] que, no tempo [in der Zeit], ela tenha desaparecido [verschwunden], e que, no espaço [im Raume], estando distante [ferne gewesen], precisamente permaneça distante [schlechthin ferne bleibt].

Trata-se de passagem que não tem o objetivo de apresentar a definição do que é esperança, mas faz uso do termo esperança em relação com os conceitos de "contingência" (Zufälligkeit) e de "necessidade" (Notwendigkeit - do que é "necessário" [notwendig]), de "tempo" (Zeit) e "espaço" (Raume), de "cumprimento" (Erfüllung), etc. Alguns aspectos parecem ser ou ficar compreensíveis, outros nem tanto. Mas, são elementos, como ainda veremos, que ajudarão a compreender o significado do conceito hegeliano de esperança.

Ora, o termo esperança ocorre mais vezes na citada obra, mas se destaca principalmente uma passagem do "Prefácio" (Vorrede) da Fenomenologia do Espírito (2003, p. 69-70 [TN] [3/66]), em que Hegel afirma o seguinte:

Considero, aliás [ferner], que o que há de excelente na filosofia de nosso tempo [Vortreffliche der Philosophie unserer Zeit] coloca seu valor mesmo [Wert selbst] na cientificidade [Wissenschaftlichkeit]; e embora outros o considerem de outra forma, de fato, apenas [nur] pela cientificidade [durch sie] a filosofia se faz valer [sich geltend macht]. Assim [Somit], posso esperar também [kann ich auch hoffen] que essa tentativa [Versuch] de reivindicar [vindizieren] a ciência para o conceito [die Wissenschaft dem Begriffe], e de apresentá-la $[$ sie ... darzustellen] nesse seu elemento próprio [ihrem eigentümlichen Elemente], saberá abrir uma passagem [Eingang], por meio da verdade interior da Coisa [innere Wahrheit der Sache].

Trata-se de passagem essencial, pois Hegel usar o verbo "hoffen", isto é, "esperar", vinculado a sua constante preocupação de que a filosofia precisa se elevar à "cientificidade [Wissenschaftlichkeit]", de usar a forma do "conceito [Begriff]" e não do mero "arrazoar [Räsonieren]"7. Mas, não trataremos aqui sobre o conceito hegeliano de Filosofia e de Ciência, apenas ressaltamos que Hegel registra o aspecto do "posso... esperar [kann... hoffen]" e, assim, vemos a relação de "esperança [Hoffnung]" e do que "eu posso... esperar [ich darf... hoffen]", em função da resposta à pergunta: "O que eu posso esperar? [Was darf ich hoffen?]" convém citar e destacar o chamado "discurso" de Hegel no "início do magistério filosófico na Universidade de Berlim [Antritt des philosophischen Lehramtes an der Universität Berlin]", de 22.10.1818, que consta como "apêndice" na Enciclopédia ([TN] [10/309 e 404]):

No que diz respeito ao momento no tempo [Zeitpunkt], as circunstâncias parecem ter surgido sob as quais a filosofia pode [darf] de novo se prometer [versprechen] atenção e amor [Aufmerksamkeit und Liebe] - em que esta ciência quase muda [verstummte Wissenschaft] pode levantar novamente a sua voz [ihre Stimme wieder erheben mag]. [...]. Eu posso desejar e esperar [Ich darf wünschen und hoffen] que, no caminho que entramos, tenha sucesso em ganhar e merecer sua confiança [Vertrauen]; mas, inicialmente, eu nada posso [darf ich nichts] reivindicar exceto que vocês tragam consigo a confiança na ciência, crença na razão, confiança e crença em si mesmo. A coragem da verdade, a crença no poder do espirito é a primeira condição do estudo filosófico [ist die erste Bedingung des 
philosophischen Studiums]; [...]

Além disso, isso remete a outro discurso de Hegel, proferido dois anos antes, ao então apresentar-se na Universidade de Heidelberg, em 28.10.1816, assumindo nela a cátedra de filosofia. Inicialmente ([TN] [18/11]), consta o seguinte:

[...] parece chegado o momento no tempo [Zeitpunkt] em que a filosofia [die Philosophie] pode [darf] se prometer de novo [sich wieder ... versprechen] atenção e amor [Aufmerksamkeit und Liebe]; esta ciência quase emudecida [diese beinahe verstummte Wissenschaft] pode levantar de novo sua voz [Stimme] e pode esperar [hoffen darf] que o mundo [Welt], que ficou surdo [taub] para ela [für sie], volte a dar de novo ouvido a ela [ihr wieder ein Ohr leihen wird].

Depois disso ${ }^{10}$, Hegel ([TN] [18/12]) afirma ou conclama o seguinte:

Eu dediquei a minha vida à ciência [Ich habe mein Leben der Wissenschaft geweiht] e alegro-me por ter alcançado uma posição [Standorte] em que eu possa colaborar [mitwirken], em medida mais alta e em campo mais vasto de ação, na difusão e no reavivamento [Verbreitung und Belebung] pelo interesse científico superior [höheren wissenschaftlichen Interesses] e, inicialmente, poder contribuir para sua introdução. Eu espero [Ich hoffe] que tenha sucesso em ganhar e merecer sua confiança [Vertrauen]. Mas, inicialmente, eu nada posso [darf ich nichts] reivindicar exceto apenas que vocês tragam consigo acima de tudo a confiança na ciência e a confiança em si mesmos. A coragem da verdade, a crença no poder do espirito é a primeira condição da filosofia [die erste Bedingung der Philosophie]. [...]

Os dois discursos, distantes dois anos (1816 e 1818), destacam a "esperança [Hoffnung]" ou o "esperar [hoffen]" de Hegel, entre outros, como professor de filosofia numa universidade, com uma pequena diferença: em 1816, Hegel afirma: "Eu espero [Ich hoffe] [...]" e, em 1818, afirma: "Eu posso desejar e esperar [Ich darf wünschen und hoffen] [...]". Destaque para o verbo modal alemão "darf -dürfen", como veremos. Além disso, no caso, ao responder a dita pergunta: "O que eu posso esperar? [Was darf ich hoffen?]", afirma "esperar [hoffen]" ter sucesso em "ganhar e merecer a confiança [Vertrauen]" da então comunidade acadêmica. Ora, são aspectos históricos e crítico-filológicos que nos permitem compreender melhor o que Hegel esperava ou tem como esperança ao assumir então a cátedra de filosofia e, também, já nos mostra alguns aspectos do seu conceito de esperança.

Entretanto, alguém poderia questionar: afinal, qual é o conceito hegeliano de esperança? Ora, a resposta mais clara e direta parece estar nas Lições sobre a Filosofia da Religião, ao falar sobre "A forma do sentimento" (Die Form des Gefühls), a saber:

O sentimento pode ter o conteúdo mais variado; temos um sentimento de certo, errado, Deus, cor, ódio, inimizade, alegria, etc.; encontra-se nele o conteúdo mais contraditório: o mais baixo e o mais alto, o mais nobre tem nele seu lugar. É uma experiência que o sentimento tem o conteúdo mais contingente [zufälligsten Inhalt]; esse pode ser o mais verdadeiro e o pior. [...] $\mathrm{O}$ fato de estar um conteúdo no sentimento não traz nada extraordinário para ele mesmo. Porque não apenas o que é entra em nosso sentimento, não apenas o real, o essente, mas também o fictício, o mentiroso, tudo de bom e tudo de ruim, tudo de efetivo e tudo de inefetivo está em nosso sentimento, o mais oposto está nele. Sinto toda a imaginação de objetos, posso me entusiasmar para os mais indignos. ([TN] [16/127$128]$ ).

Depois disso, enfim, consta a seguinte afirmação:

Eu tenho esperança [Ich habe Hoffnung]. Esperança é um sentimento [Hoffnung ist ein Gefühl]; nela, como no temor [Furcht], está o futuro [Zukünftige], imediatamente algo que ainda não é [was noch nicht ist], talvez somente venha a ser [vielleicht erst sein wird], talvez nunca venha a ser [vielleicht nie sein wird]. Da mesma forma, posso estar entusiasmado com o passado [Vergangenes], mas também com coisas que não foram nem serão [weder gewesen ist noch sein wird]. ([TN] [16/128]).

Trata-se da única menção na Hegel Werke em que consta: "Esperança é... [Hoffnung ist]". No caso, o conteúdo é claro, expondo a esperança como sendo um "sentimento [Gefühl]" e, como 
tal, podendo ser o "mais contingente [zufälligsten]" possível, podendo ser uma ou a esperança "mais baixa [Niederträchtigste]" ou "mais alta [Höchste]" ou, ainda, a "mais nobre [Edelste]", a "mais verdadeira [wahrhafteste]" ou a "pior (ou mais inferior) [schlechteste]", ser também uma esperança "real [Reale]", "fictícia [Erdichtete]", "mentirosa [Erlogene]", "efetiva [Wirkliche]" ou "inefetiva (não-efetiva) [Nichtwirkliche]", "boa [Gute]" ou "má [Schlechte]", etc. Mas, outro 200 aspecto esclarecedor, como veremos, é a relação entre "esperança [Hoffnung]" e "temor [Furcht]" e, no caso, envolvendo os conceitos de "futuro [Zukunft]" e de "passado [Vergangenheit]"; ora, sobre isso, por exemplo, na Enciclopédia, no § 259 ([TN] [9/51-52]), Hegel fala sobre as "dimensões do tempo [Dimensionen der Zeit], o presente [Gegenwart], o futuro [Zukunft] e o passado [Vergangenheit]", sendo "o presente enquanto agora [Jetzt]" e, em seguida, no $§ 259$ A ([TN] [9/52]), afirma:

O presente finito [endliche Gegenwart] é o agora [Jetzt] fixado como essente, como unidade concreta e, portanto, como afirmativo [Affirmative], diferente do negativo [Negativen], dos momentos abstratos do passado e do futuro [abstrakten Momenten der Vergangenheit und Zukunft]; somente esse ser é ele próprio apenas o abstrato, desaparecendo no nada. - Aliás, na natureza, em que o tempo [Zeit] é agora [Jetzt], não existe diferença existente nessas dimensões; elas são necessárias apenas na representação subjetiva, na memória [Erinnerung] e no temor ou na esperança [in der Furcht oder Hoffnung]. Mas, o passado [Vergangenheit] e o futuro do tempo [Zukunft der Zeit] como essente na natureza é o espaço [Raum], porque isso é o tempo negado [negierte Zeit]; então, o espaço suprassumido [aufgehobene Raum] é, inicialmente, o ponto e o tempo se desenvolve para si.

Assim, novamente a esperança ou o temor são apresentados como um sentimento ou, no caso, como uma "representação subjetiva" (subjektiven Vorstellung), isto é, uma representação de uma "subjetividade" (Subjektivität) ou de um "sujeito" (Subjekt), que se dá segundo as "dimensões do tempo [Dimensionen der Zeit]", a saber, o "presente [Gegenwart]" ou o "agora [Jetzt]", vinculado ao "passado [Vergangenheit]" e, em especial, ao "futuro [Zukunft]". Tudo depende, ainda, de um "devir (ou vir-a-ser) [Werden]", com destaque para o fato ou para a realidade de que a única "unidade concreta [konkrete Einheit]" é o "presente finito [endliche Gegenwart]" ou o "agora [Jetzt] fixado como essente [als seiend]", pois "passado e futuro [Vergangenheit und Zukunft]" são "momentos abstratos [abstrakten Momenten]". Somente o presente ou o agora é, pois o passado foi, não sendo mais, e o futuro ainda não é, pois no máximo será. Portanto, a esperança ou o esperar é por algo no futuro, que temos no presente ou agora, certamente influenciado pelo nosso passado.

Sobre isso, convém de maneira especial citar Jürgen Moltmann (2005, p. 42), em seu livro intitulado Teologia da esperança [Theologie der Hoffnung], no qual afirma:

A mais séria objeção contra uma teologia da esperança não provém da presunção nem do desespero - pois essas duas atitudes ${ }^{11}$ da existência humana pressupõem a esperança -, mas opõe-se à esperança a [...] humilde aceitação do presente [...]. A lembrança o agrilhoa ao que passou, ao que não existe mais; a esperança o atira no futuro, ao que ainda não existe. $\mathrm{O}$ passado o faz lembrar-se de ter vivido, mas não o leva a viver; o faz lembrar-se de ter amado, mas não o leva a amar; o faz lembrar-se dos pensamentos dos outros, mas não o leva a pensar. Fato semelhante parece dar-se em relação à esperança: ele espera viver, mas não vive; espera um dia tornar-se feliz, e esta espera faz com que o indivíduo passe ao largo da felicidade do presente. Ao se lembrar e ao esperar, ele jamais está inteiramente dentro de si mesmo ou em seu presente; corre sempre atrás dele ou se antecipa a ele. As lembranças e as esperanças parecem frustrá-lo quanto à felicidade de existir indivisamente no presente. Elas o privam de seu presente, arrancam-no e o lançam para tempos que não existem mais ou ainda não existem.

Moltmann (2005, p. 42) ainda cita Pascal, que "lamentou esse engano da esperança"12. Além disso, Moltmann (2005, p. 43) afirma: "Assim, o verdadeiro presente nada mais é do que a eternidade imanente no tempo. É preciso, portanto, reconhecer no brilho do temporal e do passageiro, a substância nele imanente, "o eterno que está presente"13, como dizia o jovem Hegel". Ora, não convém aqui tentar expor as demais afirmações (questionáveis ou não) do autor sobre Hegel, mas apenas ressaltar, como veremos, o problema das diversas formas de desesperança, seja de desespero ou de presunção, ou de viver no alegado engano da esperança. 
Sobre isso, nos Primeiros Escritos (Frühe Schriften) ([TN] [1/268-269]), já consta:

A frugalidade calma [ruhige Genügsamkeit] do efetivo, a desesperança [ou a falta de esperança] [Hoffnungslosigkeit], a resignação paciente [geduldige Ergebung] a um destino [Schicksal] tão grande e todo-poderoso transformaram-se em esperança [Hoffnung], em expectativa [Erwartung], em coragem [Mut] para outra coisa. A imagem de tempos melhores e mais justos [besserer, gerechterer Zeiten] chegou vivamente às almas dos seres humanos, e um anseio [Sehnsucht], um suspiro [Seufzen] por uma situação mais pura e livre [reineren, freieren Zustande], moveu todos os ânimos e dividiu-os com a efetividade. O impulso de romper as escassas barreiras atribuiu suas esperanças [seine Hoffnungen] a todos os eventos, a todos os vislumbres, até aos ultrajes cometidos. De onde o povo de Württemberg poderia aguardar ajuda mais justa do que da assembleia de suas províncias? O adiamento da satisfação dessas esperanças [Befriedigung dieser Hoffnungen], o tempo pode apenas purificar esse anseio, separar o puro do impuro, mas ele intensificará o impulso para o que ajuda um carecimento verdadeiro, esse desejo apenas se aprofundará através da hesitação nos corações; não é uma vertigem acidental que passa.

Além disso, nos Escritos de Nuremberg e de Heidelberg, mais precisamente no chamado "Discurso de final de ano letivo de 02.09.1811" ([TN] [4/344]), consta:

No tempo [Zeit] em que o curso de estudo foi aberto, que agora finalizamos, parecia por um longo tempo [Zeitlang] duvidoso que celebraríamos esta cerimônia [...]. [...] preocupações [Besorgnisse] com a iminente dissolução da escola secundária [...] [mas,] ao menos, tiveram o efeito público [öffentliche Wirkung] de [...] produzir uma causa [Veranlassung] e uma esperança de fazer algo de bom [eine Hoffnung hat, etwas Gutes zu bewirken]. As recentes mudanças do tempo [Zeitumwälzungen] provocaram tantas vezes: indiferença [Gleichgültigkeit], desesperança [Hoffnungslosigkeit] e perda [Verlust] da crença [ou fé] [Glaubens], outrora tão poderosa, de que o cidadão pode ser eficaz para o bem comum [...].

Enfim, como vemos, a desesperança ou a falta de esperança (Hoffnungslosigkeit) é exposta como um grande problema, junto com a "resignação paciente [geduldige Ergebung]", a "indiferença [Gleichgültigkeit]", etc. Assim, é necessário haver "esperança [Hoffnung]", sobretudo de que podemos esperar e fazer um futuro melhor.

Assim sendo, em resumo, ter esperança é esperar algo, mas, segundo Hegel, devemos antes procurar devida resposta para a pergunta: "O que eu posso [darf] esperar? [Was darf ich hoffen?]", lembrando que, no caso, se usa o verbo modal "dürfen (poder = ter permissão, aval, licença)" e não o verbo "können (poder)". Infelizmente, em português, usa-se normalmente para ambos o verbo "poder", mas Hegel nos diria que alguém até "pode" (kann - können) ter esperança ou esperar qualquer coisa (pois "können" remete à capacidade ou possibilidade), mas provavelmente não "deve" (soll - sollen), pois, "precisa" ou "tem que" (muss - müssen) ver se sua esperança ou seu esperar não é, por exemplo, algo utópico, ilusório, etc. Ora, em alemão, existe até a afirmação: "Du kannst, aber darfst nicht...", isto é, "Tu podes (enquanto capacidade ou possibilidade), mas não podes... (enquanto permissão, aval, licença)". Além disso, se poderia ainda usar os outros dois verbos modais (Modalverben) em alemão, afirmando que alguém até pode "querer" (wollen) ou "gostar de" (mögen) ter esperança ou esperar qualquer coisa, porém fica novamente a pergunta: Eu posso [darf] esperar isso ou, então, isso me é permitido? ${ }^{14}$

Certamente não é fácil saber o que posso [darf] esperar ou o que me é permitido esperar, afinal se soubesse claramente então não envolveria propriamente "crença" ou "fé" (Glauben), lembrando da tríade: "fé, amor e esperança [Glaube, Liebe und Hoffnung]", a qual Hegel cita inclusive literalmente no $\S 359$, penúltimo $\S$ da Filosofia do Direito (2010, p. 313 [7/511]); mas não analisaremos aqui maiores detalhes sobre o "amor" (Liebe) ${ }^{15}$, apenas alguns aspectos sobre a "crença" ou "fé" (Glauben).

Agora, na sequência do artigo, procuraremos ver principalmente a relação do conceito de esperança com o conceito de "temor" [ou "medo"] (Furcht).

\subsection{Relação entre esperança (Hoffnung) e temor (Furcht) em Hegel}

Sobre a relação de "esperança" (Hoffnung) com "temor" [ou "medo"] (Furcht) ${ }^{16}$, em 
suma, Hegel nos apresenta várias possibilidades ou realidades: por exemplo, fazer ou deixar de fazer algo "por temor ou esperança [von / aus Furcht oder Hoffnung]", "no temor ou na esperança [in der Furcht oder Hoffnung]", "em temor e esperança [in Furcht und Hoffnung]", "entre temor e esperança [zwischen Furcht und Hoffnung]", "entre o temor [...] e a esperança [zwischen der Furcht... und der Hoffnung], "nem esperança, nem temor [noch Hoffnung, noch Furcht]". Abaixo, vamos expor as ocorrências das expressões acima.

Ora, na Filosofia do Direito, no $§ 147$ A (2010, p. 168-169 [7/295-296]), Hegel afirma:

Crença [ou fé] e confiança [Glaube und Zutrauen] pertencem à reflexão iniciante e pressupõem uma representação e uma diferença; - como, por exemplo, é diferente crer na religião pagã e ser pagão. Aquela relação, ou antes aquela identidade sem relação, na qual o ético é a vitalidade efetiva da autoconsciência, pode, contudo, passar a uma relação de crença [ou de fé] e de convicção [Verhältnis des Glaubens und der Überzeugung] e a uma relação mediatizada por uma reflexão ulterior, a um discernimento [Einsicht] através de razões [Gründe] que podem também começar por quaisquer fins, interesses e considerações particulares, por temor ${ }^{17}$ ou esperança [von Furcht oder Hoffnung] ou por pressuposições históricas. Mas seu conhecimento adequado pertence ao conceito pensante [denkenden Begriffe].

Assim, ele relaciona "crença [ou fé]" (Glaube), "confiança" (Zutrauen), "convicção" (Überzeugung), entre outros, com "discernimento" (Einsicht) através de "razões" (Gründe), que teria sido feito, no caso, "por temor ou esperança" (von Furcht oder Hoffnung). Trata-se de conteúdo que não requer maior apresentação ou análise, pois sua compreensão é fácil.

Além disso, nas Lições sobre a História da Filosofia ([TN] [19/330]), consta:

O que Epicuro diz sobre os deuses ainda pode ser dito em parte. [...] que Deus é este abençoado, que apenas deve ser respeitado [geachtet] por ele mesmo, é muito correto. Epicuro atribui este conhecimento ao fato de que Deus é universal, evidente, energia, etc. Portanto, o primeiro elemento é a adoração aos deuses [Verehrung der Götter], não por temor ou esperança [nicht aus Furcht oder Hoffnung].

No § 259 A, da Enciclopédia ([TN] [9/52]), que já vimos, consta que "elas [as dimensões do tempo, a saber, presente, futuro e passado] são necessárias apenas na representação subjetiva, na memória e no temor ou na esperança [in der Furcht oder Hoffnung]".

Nos Primeiros Escritos (Frühe Schriften), de 1798 ([TN] [1/445]), ao falar curiosamente sobre "jogo de cartas" (Kartenspiel), afirma-se o seguinte:

A inclinação para o jogo de cartas [Kartenspiel] é uma característica principal no caráter de nosso tempo [Charakter unserer Zeit]. Entendimento e paixão [Verstand und Leidenschaft] são as características da alma que nele atuam. Esse busca as regras e as aplica a todo o momento como poder de julgamento. Por isso, pessoas de profunda razão e imaginação brilhante são frequentemente jogadores ruins, não apenas porque podem não estar interessados no jogo, porém também porque seu poder de julgamento não é muitas vezes exercido da mesma forma na aplicação constante de regras à vida quotidiana. Paixão [Leidenschaft] é o que principalmente dá interesse. Para o jogador frio [kalten Spieler], que ao mesmo tempo não joga para ganhar [Gewinnsucht], o jogo de cartas é de particular interesse como exercício do entendimento e do poder do julgamento. Mas, de resto, para além do desejo de vencer [Lust nach Gewinn], a mudança de paixão em temor e esperança [der Wechsel der Leidenschaft in Furcht und Hoffnung] é a circunstância que torna o jogo de cartas tão geral [...]. É esse humor apaixonado e inquieto do espírito que caracteriza o nosso tempo [Zeitalter] e ao qual o jogo de cartas também agradece a sua propagação.

Também nos Primeiros Escritos, de 1798 ([TN] [1/268]), ao falar sobre "as mais recentes relações internas de Württemberg", consta: "Estava no tempo do povo de Württemberg emergir de suas oscilações [Schwanken] entre temor e esperança [zwischen Furcht und Hoffnung], de sua alternância de expectativa [aus seiner Abwechslung von Erwartung] e de ilusão nessa expectativa [von Täuschung in dieser Erwartung]". Convém aqui destacar a relação especial entre os conceitos de "tempo [Zeit]", de "temor [Furcht]", de "esperança [Hoffnung]", de "expectativa [Erwartung]" ou "aguardar [erwarten]" e de "ilusão [Täuschung]". Como saber realmente se o que tememos, esperamos ou aguardamos não é uma mera ilusão? 
Igualmente nos Primeiros Escritos, mas agora de 1794 ([TN] [1/81), ao falar de supostas "Doutrinas teóricas misteriosas [Mysteriöse theoretische Lehren]", consta:

Uma doutrina do Cristianismo diferente, desconhecida da razão, é a alternativa temerosa [fürchterliche Alternative], em que não há meio-termo [Mittleres], que o destino [Schicksal], que aguarda os seres humanos em outro mundo, ou é a felicidade eterna [ewige Seligkeit] ou é a condenação eterna [ewige Verdammnis], - uma alternativa [...] de que o ser humano nesta vida, após a qual o reino da graça [Reich der Gnaden] tem um fim e o reino da justiça implacável [Reich der unerbittlichen Gerechtigkeit] começa, deixa nenhum momento de paz [Ruhe], porém o coloca numa situação de incerteza mais angustiante, que no sentimento de sua imperfeição eternamente oscilou entre o temor do juiz do mundo e a esperança do misericordioso pai que perdoa [zwischen der Furcht vor dem Richter der Welt und der Hoffnung von dem gnädigen verzeihenden Vater] - uma situação dolorosa, que apenas é menos frequente porque a natureza do ser humano é inconsequente com a de seus princípios, que não são fundados em si mesmos, porém são levados à cabeça apenas de fora.

E nas Lições sobre a Filosofia da História ([TN] [12/382]), ao falar da morte de Nero, como "exemplo para o herói mais nobre e também para o ser humano mais resignado", consta:

A subjetividade particular, em seu desapego completo, não tem interioridade, nem avança ou retrocede, nenhum arrependimento [keine Reue], nem esperança [noch Hoffnung], nem temor [noch Furcht], nenhum pensamento [keinen Gedanken], - pois tudo isso contém determinações e fins fixos; mas aqui toda a determinação é completamente contingente [völlig zufällig]. Ela é a luxúria [Begierde], o desejo [Lust], a paixão [Leidenschaft], a inspiração [Einfall], em suma, o arbítrio [Willkür] em sua total indelimitação [gänzlichen Unbeschränktheit].

São várias passagens sobre a relação entre "esperança [Hoffnung]" e "temor [Furcht]", com suas nuanças, que ficam manifestas nas citações acima. Agora, abaixo, veremos a relação entre esperança, temor e outros sentimentos em Hegel, com mais detalhes sobre os conceitos.

\subsubsection{Relação entre esperança, temor e outros sentimentos em Hegel}

Hegel afirma, entre outros, no § 472 Z, da Enciclopédia (1995, p. 268 [TN] [10/293-294]) que há toda uma "classe de sentimentos [Klasse von Gefühlen] ${ }^{18}$, por exemplo, o prazer [Vergnügen], a alegria [Freude], a esperança [Hoffnung], o medo [ou o temor] [Furcht], a angústia [Angst] ${ }^{19}$, a dor [Schmerz] etc.", os quais, são "sentimentos que - por seu conteúdo provir da intuição ou da representação - excedem em determinidade o sentimento do agradável ou desagradável". Inclusive, na sequência do $\S 472 \mathrm{Z}$, consta um esclarecimento de alguns dos sentimentos, em especial do "medo [ou temor] [Furcht]":

A alegria [Freude] consiste [besteht] no sentimento [Gefühl] do acordo singular do meu serdeterminado-em-si-e-para-si com um evento singular, com uma Coisa ou pessoa. A satisfação [Zufriedenheit], ao contrário, é mais um acordo duradouro, pacifico, sem intensidade. No contentamento [Heiterkeit], mostra-se um acordo mais caloroso. O medo [ou temor] [Furcht] é o sentimento de meu si [Selbstes] e, ao mesmo tempo, de um mal [Übels] que ameaça destruir meu sentimento-de-si [ou meu autossentimento] [Selbstgefühl]. No pavor [ou terror] [Schrecken], sinto o desacordo súbito de algo exterior com meu sentimento-de-si [ou autossentimento] positivo. Todos esses sentimentos [Gefühle] carecem de conteúdo imanente, que pertença à sua natureza própria; o conteúdo lhes vem de fora.

Sobre isso, nas Lições sobre a Estética, no subcapítulo intitulado: "A obra de arte como produção sensível dirigida para o sentido humano", fala-se sobre "quais sentimentos devem, afinal, ser suscitados pela arte" e, no caso, cita como exemplos: o "temor [Furcht] e [a] compaixão [Mitleid]" (2001, p. 54 [13/52]); e logo depois (2001, p. 54 [13/53]), afirma-se:

Temor [Furcht], angústia [Angst], preocupação [Besorgnis], susto [ou terror] [Schreck], por exemplo, são decerto algumas modificações [Modifikationen] de um e mesmo modo de sentir [Empfindungsweise], embora em parte sejam apenas gradações quantitativas [quantitative Steigerungen] ${ }^{20}$, em parte formas [Formen] que não tem nada a ver com o 
conteúdo [Inhalt], pois lhe são indiferentes. No temor [Furcht], por exemplo, algo de existente está presente e suscita um interesse no sujeito, ao mesmo tempo ele vê o negativo se aproximar, ameaçando destruir esta existência; as duas coisas, então, este interesse e aquele negativo, ele encontra imediatamente em si mesmo como afecção contraditória de sua subjetividade. Tal temor [Furcht], porém, não requer por si mesmo nenhum conteúdo, uma vez que pode acolher em si mesmo as coisas mais distintas e opostas.

Assim, Hegel nos apresenta alguns aspectos sobre o seu conceito de "temor [Furcht]" e, então, logo em seguida (2001, p. 54 [TN] [13/53]), afirma o seguinte:

O sentimento [Empfindung] enquanto tal é uma forma completamente vazia de afecção subjetiva [subjektiven Affektion]. É claro que esta forma pode, em parte [teils], ser em si mesma variada [mannigfach], como, por exemplo, a esperança [Hoffnung], a dor [Schmerz], a alegria [Freude], o prazer [Vergnügen], e em parte [teils] pode abranger nesta diversidade [Verschiedenheit] de conteúdos distintos, como, por exemplo, o sentimento de justiça [Rechtsgefühl], o sentimento ético [sittliches Gefühl], o sublime sentimento religioso [erhabenes religiöses Gefühl], etc.; mas, tal conteúdo, por estar presente em formas diferentes de sentimento [unterschiedenen Formen des Gefühls], ainda não vem à luz em sua natureza essencial e determinada, porém, permanece minha afecção meramente subjetiva, na qual desaparece a coisa concreta ao ser comprimida na esfera mais abstrata.

Enfim, no caso, reitera-se o que já vimos, a saber, de que a esperança é um sentimento, mas no caso, entre outros, consta também o sentimento do "temor [Furcht]", junto com uma explicação dele e dos sentimentos de modo geral.

Além disso, nas Lições sobre a Estética, depois de citar trecho do monólogo de Julieta (Ato III, cena 2), em Romeu e Julieta, de William Shakespeare, consta o seguinte:

Aqui o poeta, quando se demora em um determinado objeto comparando, tem por [...] interesse [Interesse] de nos retirar por assim dizer da curiosidade prática [praktische Neugierde], da expectativa [Erwartung], da esperança [Hoffnung] e do temor [Furcht] que cultivamos em relação ao desenlace dos acontecimentos [...] (2000, p. 142 [TN] [13/532]).

Por fim ${ }^{21}$, no rol dos vários sentimentos elencados, envolvendo esperança e temor, convém registrar uma passagem dos Primeiros Escritos ([TN] [1/266]), em que ao falar de "eleição" (Wahl), com sua "agitação" (Betriebsamkeit), suas "intrigas" (Intriguen), sua "variedade de combinações" (Mannigfaltigkeit der Kombinationen) e sua "variedade de interesses que se vinculam" (Mannigfaltigkeit der Interessen zu verknüpfen), afirma-se:

[...] a paixão [Leidenschaft], com que tudo isso é feito, ou os sentimentos [Gefühlen], que se seguem ao resultado feliz ou infeliz - da violência dessas esperanças [von der Gewaltsamkeit dieser Hoffnungen], do temor [Furcht], da angústia [Angst], da força dessa alegria [Stärke dieser Freude] ou desse desespero [dieser Verzweiflung], a fim de obter uma imagem [Bild] de tudo isso, é preciso ter visto tudo por si mesmo.

Ora, trata-se de passagem importante, destacando a relação entre "esperança [Hoffnung]", "temor [Furcht]" e "desespero [Verzweiflung]", o qual veremos melhor na sequência.

\subsubsection{Relação entre esperança, temor e desespero em Hegel}

Inicialmente, convém repetir, aqui, parte do $\S 81 \mathrm{Z}$ (2015, p. 166 [TN] [8/175-176]) da Enciclopédia, em que se afirma que o "ceticismo não pode ser considerado simplesmente como uma doutrina-da-dúvida [Zweifelslehre]”, pois "quem apenas duvida [nur zweifelt] está ainda na esperança [steht noch in der Hoffnung] de que sua dúvida poderá ser resolvida [sein Zweifel gelöst werden könne]"; mas, "ao contrário, o ceticismo é propriamente o desespero rematado [die vollkommene Verzweiflung] de tudo [an allem] o que há de firme no entendimento". Ora, no caso, vemos a relação entre "esperança" (Hoffnung) e "desespero" (Verzweiflung), sendo, inclusive, um "desespero rematado [vollkommene Verzweiflung]". Mas, também no "Prefácio à Segunda Edição", de 1827 (2015, p. 18 [TN] [8/16]), fala-se de "estado [ou situação] de desespero [Zustande der Verzweiflung]”, e no § 22 Z (2015, p. 76 [TN] [8/79]), afirma-se: 
[...] foi especialmente nos tempos modernos que foi suscitada a dúvida [Zweifel] - e sustentada a diferença - entre o que seriam os produtos de nosso pensar e o que seriam as coisas nelas mesmas. Foi dito que o em-si das coisas era totalmente diverso do que fazíamos [ideia] delas. O ponto de vista, que afirma esse ser-separado, foi sobretudo por meio da filosofia crítica [kritische Philosophie] que se fez valer [...]. A doença do nosso tempo [Krankheit unserer Zeit] - a qual chegou ao desespero [Verzweiflung] - é [pensar] que nosso conhecimento é apenas um conhecimento subjetivo, e que esse subjetivo é a última palavra [das Letze].

Por fim, também no "Apêndice" (Anhang) da Enciclopédia ([TN] [10/403], fala-se sobre o "desespero na razão [Verzweiflung an der Vernunft]", mencionando o então grande problema da "superficialidade do saber [Seichtigkeit des Wissens]", citando, entre outros, novamente a "assim chamada filosofia crítica [sogenannte kritische Philosophie]" e, em seguida, se afirma:

[...] este suposto conhecimento [diese vermeinte Erkenntnis] tomou até o nome da filosofia [Namen Philosophie], e nada foi mais bem-vindo à superficialidade do saber [Seichtigkeit des Wissens], bem como do caráter, nada foi tão bem-vindo como este ensino [ou esta doutrina] [Lehre], em que precisamente esta ignorância [Unwissenheit], esta superficialidade [diese Seichtigkeit] e estupidez [Schalheit] para o excelente, para o fim e o resultado foram gastos todo o esforço intelectual.

Enfim, em ambos, Hegel menciona o conceito de "desespero [Verzweiflung]" vinculado ao problema da filosofia de seu tempo ${ }^{22}$. Trata-se de aspecto que já vimos acima.

Mas, enfim, nas Lições sobre a Estética (2000, p. 145 [TN] [13/536]), ao falar do velho Northumberland na obra Henrique IV, de William Shakespeare, consta o seguinte:

Se tivermos um ânimo diante de nós, ao qual deve sobrevir um grande infortúnio [großes Unglück], por meio do qual ele é arruinado [zerrüttet] no mais íntimo [Innersten], e efetivamente sucede a dor [Schmerz] de um destino irrecusável, então seria da espécie de uma natureza ordinária gritar imediatamente o susto [ou o terror] [Schreck], a dor [Schmerz], o desespero [Verzweiflung] e, desse modo, aliviar-se. Um espírito forte, nobre [kräftiger, adliger Geist], guarda a lamentação [Klage] enquanto tal para si, mantém a dor [Schmerz] capturada e conserva para si, desse modo, a liberdade de se ocupar no sentimento profundo do sofrimento [tiefen Gefühl des Leidens] mesmo ainda com o mais distante na representação e neste distante expressar para si seu próprio destino em imagem.

No caso, trata-se do "desespero [Verzweiflung]" como sendo um "sentimento profundo do sofrimento [tiefen Gefühl des Leidens]", o qual se vincula ao "totalmente desesperado" ou ao em "desespero completo" (Verzweiflungsvolle), que pode levar a "um impulso irresistível ao suicídio" (ein unbezwingbarer Trieb zum Selbstmord), o qual veremos a seguir.

\subsubsection{A relação entre esperança, temor, desespero e suicídio em Hegel}

O uso hegeliano do conceito de "vida" (Leben) e de "morte" (Tod) não se dá apenas sob o aspecto natural (biológico, físico, etc.), mas também lógico e espiritual, sendo que isso afeta a questão do ser humano poder "se matar" (sich töten - sich umbringen) ou de cometer "suicídio" (Selbsttötung - Selbstmord). Ora, o problema é apresentado em Hegel, por exemplo, no § 47 A, da Filosofia do Direito (2010, p. 87 [TN] [7/110-111]), em que consta o seguinte:

O fato de que eu sou [ou estou] vivo [lebendig] e tenho um corpo orgânico não segundo o aspecto pelo qual existo como o conceito sendo para si, mas como o conceito imediato, repousa sobre o conceito da vida e o do espírito enquanto alma [Begriffe des Lebens und dem des Geistes als Seele] [...]. Eu tenho esses membros, a vida [das Leben], apenas $n a$ medida em que eu quero [ich will]; o animal não pode se mutilar ou se matar [ou se suicidar], mas o ser humano pode [das Tier kann sich nicht selbst verstümmeln oder umbringen, aber der Mensch].

No $47 \mathrm{Z}$ ([TN] [7/111]), ainda consta: "Os animais têm certamente a posse de si [...]; mas eles não têm nenhum direito à sua vida, porque não a querem [nicht wollen]”. Ora, antes disso, já no $\S 5 \mathrm{Z}([\mathrm{TN}][7 / 51])$, consta também o seguinte: 
Nesse elemento do querer [Willens], reside que eu possa me desligar de tudo, renunciar todos os fins, abstrair de tudo. Somente o ser humano pode desistir de tudo, também de sua vida [auch sein Leben]: ele pode cometer suicídio [er kann einen Selbstmord begehen]; o animal [das Tier] não pode fazê-lo [o suicídio]; ele [animal] permanece sempre apenas negativo, numa determinação estranha a ele, na qual ele apenas se habitua.

Assim, todas as passagens ressaltam que a vida natural é um aspecto importante, mas a vida espiritual, com devida consciência e propriedade, envolvendo querer ou vontade, é o que propriamente dá valor a uma vida humana, sendo que o extremo que serve como elemento de distinção em relação aos animais é a capacidade do ser humano de "se mutilar" (sich verstümmeln) ou até mesmo de "se matar [ou se suicidar]" (sich umbringen), de que "ele pode cometer suicídio" (er kann einen Selbstmord begehen). A diferença entre o ser humano e os animais, segundo Hegel, se dá pelo grau de consciência, de ciência, de querer, de vontade envolvida na vida. Isto é, o fato do "animal" ou do "bicho" (Tier - Vieh) "ter" (haben) "vida" (Leben), para o autor, isso não lhe dá o respectivo direito à sua vida, pois não a quer racionalmente, mas a tem apenas de forma instintiva. A vida humana, a fim de não ser uma vida meramente animal, requer o querer consciente da vida e, assim, envolve até o outro extremo, isto é, de não "matar" (töten - umbringen) a própria vida, de não "se matar" (sich töten - sich umbringen), de não cometer "suicídio" (Selbsttötung - Selbstmord).

Todavia, é importante ressaltar que Hegel está falando da "possibilidade" (Möglichkeit) ou do "poder" (können) se matar ou cometer suicídio, mas não defendendo ou estimulando a prática, antes pelo contrário. No $\S 70 \mathrm{Z}$ ([TN] [7/152]), inclusive consta o seguinte:

[...] mas, pode [ou é permitido] o ser humano tirar de si mesmo a vida? [aber darf der Mensch sich selbst das Leben nehmen?] Pode-se considerar o se matar [das sich Töten], em primeiro lugar, como uma coragem [Tapferkeit], porém como uma má [schlechte] coragem, a dos alfaiates e das criadas. Pode-se, por sua vez, considerá-lo como uma infelicidade [ou desgraça] [Unglück], na medida em que leva a dilaceração do interior [Zerrissenheit des Inneren]. Mas, a pergunta principal é: eu tenho um direito a isso? [habe ich ein Recht dazu?] A resposta será que eu, enquanto este indivíduo, não sou senhor da minha vida [ich als dies Individuum nicht Herr über mein Leben bin], pois a totalidade que compreende a atividade, a vida [das Leben], não é algo exterior em face da personalidade [Persönlichkeit], a qual é ela mesma [a vida] esta personalidade imediata. Portanto, falar-se de um direito que a pessoa tem sobre a sua vida [von einem Recht, das die Person über ihr Leben habe] é, assim, uma contradição (Widerspruch), pois isso significaria que a pessoa tem um direito acima de si [ein Recht über sich]. Mas, ela não tem esse direito, pois ela não está acima de si mesma [steht nicht über sich] e não pode [kann] se julgar [richten]. Quando Hércules se queimou [ou se entregou às chamas] [sich verbrannte], quando Brutus jogou-se sobre sua espada [sich in sein Schwert stürzte], este é um comportamento de um herói contra a sua personalidade [gegen seine Persönlichkeit]; mas quando se trata do simples direito de se matar [vom einfachen Recht, sich zu töten], assim pode [ou é permitido] [so darf] isso ser negado [abgesprochen] também aos heróis.

Em suma, Hegel defende o "valor da vida" (Werte des Lebens) e é contra o suicídio, contra se matar, se suicidar, tirar sua vida, mas isso é um problema delicado e complexo. Inclusive, sobre isso, cabe citar o $§ 408 \mathrm{Z}$ da Enciclopédia (2005, p. 161 [TN] [10/175-176]):

Pode ser considerada como a loucura mais indeterminada [unbestimmtesten Narrheit] o tédio-de-viver [ou o desgosto-da-vida] [Lebensüberdruß], quando não é ocasionado pela perda de pessoas amadas, dignas de respeito, e [pela perda] de relações éticas. O nojo da vida indeterminado e infundado [unbestimmte, grundlose Ekel am Leben] não é uma indiferença quanto à vida [Gleichgültigkeit gegen dasselbe] - pois, neste caso, se suporta a vida [erträgt man das Leben] - mas, antes, a incapacidade de suportar a vida [die Unfähigkeit, es zu ertragen], um oscilar para lá e para cá, entre a atração e a rejeição a respeito de tudo que pertence à efetividade; um estar-cativo [Gebanntsein] na representação fixa da repulsa da vida [Widerlichkeit des Lebens], e ao mesmo tempo um aspirar por ir além dessa representação. Dessa relutância - surgida sem qualquer fundamento racional [vernünftigen Grund] - contra a efetividade, como também de outras maneiras de loucura [Narrheit], os ingleses são sobremodo afetados; talvez porque nessa nação o ser-obstinado [Verstocktsein] na particularidade subjetiva é tão predominante. Aquele tédio-de-viver 
[Lebensüberdruß] aparece nos ingleses sobretudo como melancolia [Melancholie], como esse cismar persistente - que não chega à vitalidade [Lebendigkeit] do pensar e do agir - do espírito sobre sua representação infeliz [seiner unglücklichen Vorstellung]. Não raramente, desse estado-de-alma [Seelenzustande] desenvolve-se um impulso irresistível ao suicídio [ein unbezwingbarer Trieb zum Selbstmord]; às vezes, esse impulso [Trieb] apenas se pode anular arrancando o totalmente desesperado [Verzweiflungsvolle] violentamente de si mesmo. Conta-se, por exemplo, que um inglês, quando tinha em mente afogar-se [sich... ersäufen] no Tâmisa, foi assaltado por bandidos: defendeu-se o melhor possível e, de repente, devido ao sentimento que despertou do valor da vida [Werte des Lebens], perdeu todos os pensamentos suicidas [alle selbstmörderischen Gedanken]. Um outro inglês, que se enforcara [sich gehenkt hatte], quando seu criado o livrou cortando a corda, recobrou não só o gosto [ou a afeição] pela vida [die Neigung zum Leben], mas também a doença da avareza [Krankheit des Geizes], pois, ao demitir o criado, descontou-lhe dois pences, porque ele cortou a corda do enforcamento sem a ordem do seu senhor. A figura indeterminada da situação da alma demente ${ }^{23}$ [verrückten Seelenzustandes] que mata toda a vitalidade [alle Lebendigkeit abtötenden] está em contraste com interesses vivos [lebendigen Interessen] [...].

No entanto, o que fazer quando passa a existir um "tédio-de-viver [desgosto-da-vida] [Lebensüberdruss]", um "nojo da vida [Ekel am Leben], uma "repulsa da vida [Widerlichkeit des Lebens]", uma "incapacidade de suportar a vida [Unfähigkeit, es zu ertragen \{das Leben\}]" ou um estar "totalmente desesperado [Verzweiflungsvolle]", até com "pensamentos suicidas [selbstmörderischen Gedanken]" ou mesmo com "um impulso irresistível ao suicídio [ein unbezwingbarer Trieb zum Selbstmord]"? No caso, segundo Hegel, trata-se de aspecto próprio de "doença [Krankheit]", que precisa de devido tratamento, especialmente para tentar recobrar "o gosto [ou a afeição] pela vida [die Neigung zum Leben]", despertar todo o "valor da vida [Werte des Lebens]" e, assim, evitar o suicídio.

Enfim, para Hegel, nenhum ser humano pode ou deve se considerar ou ser considerado uma mera "Coisa [Sache]" ou "coisa [Ding]", pois isso "despojaria [ou privaria] o ser humano de toda verdade, valor e dignidade [dem Menschen alle Wahrheit, Wert und Würde raubte]" (§ $21 \mathrm{~A}$ 2010 , p. 68 [7/73]). Inclusive, isso envolve a questão da "maioridade" (Volljährigkeit ou Mündigkeit [versus menoridade = Unmündigkeit]), da "autonomia" (Selbständigkeit ou Autonomie [versus heteronomia = Unselbständigkeit ou Heteronomie]) e/ou, então, da "autodeterminação" (Selbstbestimmung), enquanto expressão da "liberdade do espírito" (Freiheit des Geistes), de nossa "igual dignidade" (gleiche Würde). Com isso, em suma, vinculam-se os conceitos de esperança, suicídio, desespero, temor, tempo, morte e vida, como também de liberdade, dignidade, valor, autonomia versus heteronomia, maioridade versus menoridade, autodeterminação, etc. Ora, são todos elementos interligados de um todo em conexão, como um essencial "elo em toda corrente" (Glied in der ganzen Kette [TN] [18/65]).

\subsection{A relação entre esperança e outros elementos em Hegel}

A partir desse subcapítulo, infelizmente, por questão de espaço citaremos apenas os termos de relação com a esperança e os locais de publicação, sem maiores detalhes ou análises.

Assim, nos Escritos de Nuremberg e Heidelberg, § 153 ([TN] [4/50]), ao falar de "demência [Verrücktheit]" e suas "modificações diversas como loucura, delírio, frenesi, etc. [verschiedene Modifikationen wie Narrheit, Wahnsinn, Raserei usf.]”, consta:

[...] seres humanos não apenas morreram [gestorben] de alegria [Freude], porém também ficaram com delírio [wahnsinnig]; perturbação [Zerrüttung] através de paixões [Leidenschaften], amor [Liebe], orgulho [Stolz], esperança [Hoffnung], vaidade [Eitelkeit], ilusão [Täuschung]; a desconfiança [Mißtrauen] rasga a conexão com o mundo exterior; enterram [vergraben] a sua vida dentro de si, nos seus pormenores, etc. - A forma de curar [Heilart] os distúrbios da alma [Seelenstörungen] é, então, também física e espiritual [auch körperlich und geistig].

Ainda nos Escritos de Nuremberg e Heidelberg ([TN] [4/518]), ao falar das "negociações na assembleia dos estados do Reino de Württemberg", de 1815 e 1816, consta: 
Se tivesse sido possível que um povo alemão pudesse ter acolhido este evento com alegria e esperança [Freude und Hoffnung], poderia ter parecido perigoso que os estamentos dos estados [Landstände] que tinham as intenções, já mencionadas, contrárias à vontade do seu rei, se encontrassem juntas neste momento no tempo".

Nas Lições sobre a Estética (2001, p. 54 [13/53]), como já vimos, consta: “O sentimento 208 [Empfindung] enquanto tal é uma forma completamente vazia de afecção subjetiva. É claro que esta forma pode, em parte, ser em si mesma variada [mannigfach], como, por exemplo, a esperança [Hoffnung], a dor [Schmerz], a alegria [Freude], o prazer [Vergnügen]". Além disso, ao falar da "arte moderna" e suas "potências [Mächte]", consta (2001, p. 230 [13/291-292]): “[...] estas são em grande parte apenas alegorias estéreis e frias, por exemplo, do ódio [Hasses], da inveja [Neides], do ciúme [Eifersucht], em geral das virtudes e dos vícios [Tugenden und Laster], da fé [Glaubens], da esperança [Hoffnung], do amor [Liebe], da fidelidade [Treue], etc., nos quais não depositamos crença alguma [keinen Glauben]". Ainda, ao falar do "aspecto artístico" dos gregos de "entrelaçar vivamente os indivíduos-deuses com as ações humanas", consta (2000, p. 227 [TN] [14/101]): "Já na efetividade cotidiana, nas complicações de sua vida [Verwicklungen seines Lebens], em seus carecimentos [Bedürfnissen], em seus temores [Befürchtungen], em suas esperanças [Hoffnungen], o grego encontrava refúgio nos deuses". Também, ao falar do "mundo absoluto do espírito", do "processo de elevação a Deus e de reconciliação com Deus", consta (2000, p. $258[\mathrm{TN}][14 / 136])$ :

[...] o finito enquanto tal constitui o conteúdo, tanto pelo lado dos fins espirituais [geistigen Zwecke], dos interesses mundanos [weltlichen Interessen], das paixões [Leidenschaften], das colisões [Kollisionen], dos sofrimentos [Leiden] e das alegrias [Freuden], das esperanças [Hoffnungen] e das satisfações [Befriedigungen], como também pelo lado exterior, da natureza e de seus reinos e fenômenos os mais singulares.

Igualmente nas Lições sobre a Estética (2000, p. 287 [TN] [14/170]), ao falar "de fé separada da vida, da efetividade concreta do ser-aí humano, da relação positiva dos seres humanos entre si", de "relação direta com um outro" e de sentir a "unidade do amor [Einheit der Liebe], da confiança [Zutrauens], da confiabilidade [Zuversicht], dos fins e das ações na vitalidade concreta", afirma-se: "O que constitui a esperança [Hoffnung] e o anseio [ou ânsia] [Sehnsucht] do interior, o ser humano encontra em sua interioridade abstratamente religiosa apenas como vida no Reino de Deus, na comunidade com a Igreja [...]". Além disso, consta (2000, p. 301 [TN] [14/187-188]) o seguinte:

Particularmente em tempos recentes [neueren Zeiten] vemos com frequência nos dramas, contos e romances tais colisões exteriores \{que se opõem ao amor [Liebe]: [isto é,] paixão [Leidenschaft], preconceitos [Vorurteile], estreiteza [Borniertheiten], egoísmo [Eigensinn], etc.\}, que então interessam principalmente pelo lado da participação nos sofrimentos [Leiden], nas esperanças [Hoffnungen] e nas perspectivas destruídas dos amantes infelizes [zerstörten Aussichten der unglücklich Liebenden] e, por meio de um desenlace bom ou ruim, devem comover e satisfazer [rühren und befriedigen] ou em geral apenas entreter [unterhalten].

Além disso, ao falar de "Maria, Cristo, os atos e destinos dos apóstolos, os santos", como "indivíduos totalmente determinados [ganz bestimmte Individuen]", afirma-se (2000, p. 128 [TN] $[14 / 515])$ :

[...] mas, o Cristianismo [Christentum] também tem a ver, de igual modo, com essencialidades espirituais universais [allgemeinen geistigen Wesenheiten], as quais não permitem tomar corpo [verkörpern] de modo determinado pessoas vivas, efetivas [lebendiger, wirklicher Personen], já que elas devem ser justamente expostas enquanto relações universais [als allgemeine Verhältnisse], como, por exemplo, o amor, a fé, a esperança [wie z. B. Liebe, Glaube, Hoffnung].

Por fim, ao falar dos "sentimentos [Empfindungen]", "em particular do amor [besonders der Liebe]", com "seus sofrimentos e seu prazer [ihrer Leiden und ihrer Lust]", consta (2000, p. 139 [TN] [14/529]): "Os enamorados [ou os amantes] [Verliebte] são sobretudo ricos [reich] em desejos [Wünschen], esperanças [Hoffnungen] e ideias mutáveis [wechselnden Einfällen]”. 
Nas Lições sobre a Filosofia da Religião ([TN] [17/459]), ainda se afirma o seguinte:

Esta liberdade de abstração não é sem dor [ohne Schmerz], mas reduzida à dor natural [Naturschmerz], sem a dor do arrependimento [Schmerz der Reue], da indignação [Empörung] [por causa] da injustiça, como sem consolo e esperança [ohne Trost und Hoffnung]; mas também não precisa de consolo, pois o consolo pressupõe uma reivindicação que ainda se mantém e se afirma, e apenas, não satisfeita de uma forma, exige um substituto de outra, na esperança [in der Hoffnung] de que mais um desejo seja retido.

Nas Lições sobre a História da Filosofia ([TN] [19/597]), também consta: “[...] Cristo, como uma existência passada [vergangene Existenz], está [ou é] [ist] apenas [nur] colocado na memória [Erinnerung] e na esperança [Hoffnung]".

Nos Primeiros Escritos ([TN] [1/227]), ao falar da "formação de Jesus" (Bildung des Jesus), que não envolve maiores detalhes sobre vários anos de sua vida (sobretudo na infância e na adolescência), consta: "De repente, ele aparece jovem [jugendlich] com toda esperança alegre e confiança indubitável do sucesso [aller freudigen Hoffnung und zweifellosen Zuversicht des Erfolgs]". Ainda ([TN] [1/297]), ao falar do "povo judeu no tempo de Jesus", fala de sua "confiança e esperança [Zuversicht und Hoffnungen]". Também ([TN] [1/545]), ao falar da "História e Crítica da Constituição do Reino Alemão", afirma-se que: "[...] a Liga dos Principados Alemães nada mais fez do que o emprego da opinião pública e a estimulação de muitas esperanças ou preocupações [vieler Hoffnungen oder Besorgnisse]". Por fim, nos Escritos de Berlim ([TN] [11/90]), ao falar "Sobre a Lei de Reforma [Eleitoral] Inglesa", consta: "O que desperta grande interesse é a preocupação, por uma parte, e a esperança, por outra parte [die Besorgnis einerseits, die Hoffnung andererseits], de que a reforma do direito eleitoral conduza a outras reformas materiais". São várias menções cujo significado é claro.

Além disso, constam passagens sobre a relação de esperança com aspectos religiosos. Assim, por exemplo, na Filosofia do Direito, § 270 A, ao "abordar a relação do Estado com a religião", fala-se de "esperança da religião [Hoffnung der Religion]" (2010, p. 243 [7/418]) e de "esperança de reparação da perda [Hoffnung zum Ersatz des Verlustes]" nos "tempos de miséria pública [Zeiten öffentlichen Elends]" (2010, p. 241 [7/416]). Além disso, já nos Primeiros Escritos ([TN]), fala-se de: "esperança da imortalidade [Hoffnung der Unsterblichkeit]", no caso, "imortalidade da alma [Unsterblichkeit der Seele]" ([1/53]), "esperança de salvação [Hoffnung der Errettung]" ([1/79]), "esperança de uma continuação da existência pessoal [Hoffnung einer Fortdauer der persönlichen Existenz]" ([1/80]), "esperança de uma compensação pelo sofrimento sofrido [Hoffnung einer Entschädigung für ausgestandene Leiden]" ([1/80]), esperança do misericordioso pai que perdoa [Hoffnung von dem gnädigen verzeihenden Vater]" ([1/81]), "esperança de uma bem-aventurança eterna [Hoffnung einer ewigen Seligkeit]" ([1/90]), "esperança de bem-aventurança [Hoffnung der Seligkeit]" ([1/123]), "esperança de indulgência [Hoffnung der Verschonung]" ([1/240]), "esperança judaica [jüdische Hoffnung]" ([1/108]), "esperança de um Messias vindouro [Hoffnung eines kommenden Messias]" ([1/296]), “esperança de Jesus [Hoffnung Jesu]" ([1/398]), "fé e esperança comunitária [gemeinschaftlichen Glauben und Hoffnung]" (1/407])24. Nas Lições sobre a História da Filosofia, fala-se também de "esperança de sua bem-aventurança [Hoffnung seiner Seligkeit]" ([20/51]).

Também constam passagens sobre esperança com especificação de adjetivos ${ }^{25}$. Assim, por exemplo, fala-se de: "sem esperança [ohne Hoffnung]" (três vezes [1/79, 1/82 e 19/126]), "pouca esperança [wenig Hoffnung]" (duas vezes [15/338 e 19/141]), "esperança vazia [leere Hoffnung]" ([2/487]), "nenhuma grande esperança [keine große Hoffnung]" ([4/481]), "esperanças fracas [schale Hoffnungen]" ([4/431]), "esperanças fracassadas [fehlgeschlagene Hoffnungen]" ([1/35]), "esperanças despedaçadas [zerscheiternden Hoffnungen]" ([14/190]), "esperanças banais [abgeschmackten Hoffnungen]" $([5 / 266])^{26}$, "esperança egoísta [ou egocêntrica] [eigennütziger Hoffnung]" ([16/57]), etc. Ainda se fala de: "esperança alegre [freudigen Hoffnung]" ([1/227]), "esperança interessante [interessante Hoffnung]" ([11/177]), "muita esperança [viele Hoffnung]" ([1/273]), "esperança muito maior [viel größere Hoffnung]" ([1/158]), "esperanças mais queridas [ou amadas] [liebste Hoffnungen]" ([4/368]), "esperança mais bela [schönsten Hoffnung]" ([18/395]), "esperança melhor [besten Hoffnung]" (11/352), "esperanças melhores [bessere Hoffnungen]" (1/107) e "esperanças mais altas [höhere 
Hoffnungen]" ([19/16]). No caso, importa a questão do(s) adjetivo(s), que é relativamente claro.

Mas, falando em adjetivo(s), convém destacar algumas passagens dos Escritos de Nuremberg e Heidelberg, em que se fala de: "esperanças iludidas [getäuschte Hoffnungen]" ([TN] [4/310]), de "esperanças infundadas [ungegründete Hoffnungen]" ([TN] [4/362]) e, ainda, de "total ilusão de suas esperanças [gänzlicher Täuschung ihrer Hoffnungen]" ([TN] [4/552]); e, 210 nas Lições sobre a Estética, fala-se igualmente de "esperança iludida [getäuschten Hoffnung]" ([TN] [15/473]) e de "esperanças vãs [vergeblichen Hoffnungen]" ([TN] [15/473]); ora, isso se contrapõe a uma "esperança verdadeira [wahrhafte Hoffnung]", que consta também nas Lições sobre a Estética (2000, p. 247 [TN] [14/124-125]). Trata-se de aspecto relevante, destacando que existem esperanças verdadeiras e, também, esperanças que iludem/enganam ${ }^{27}$.

Por fim, destacamos passagens sobre esperança de caráter político ou de filosofia política. Assim, nos Primeiros Escritos, fala-se já de "esperanças políticas [politischen Hoffnungen]" ([TN] [1/208]) e de "colocar uma esperança a essas esperanças [solche Hoffnungen eine Hoffnung zu setzen]" ([TN] [1/591]), ao falar da então situação política da Alemanha. Ora, nas Lições sobre a História da Filosofia, ao falar do povo jônico, de sua subjugação e escravidão, consta: "ele não vê nenhuma esperança por sua liberdade [sehe er keine Hoffnung zu ihrer Freiheit]" ([TN] [18/182]). E, na Enciclopédia, no § 396 Z (1995b, p. 80 [TN] [10/85]), consta:

Ora, quando o homem [Mann] passa para a vida prática [praktische Leben], pode [kann] certamente ficar triste e indignado [verdrießlich und grämlich] com a situação do mundo [Zustand der Welt] e perder a esperança de um melhorar da mesma [die Hoffnung auf ein Besserwerden desselben verlieren]; mas apesar disso ele se instala dentro de relações objetivas, e vive na familiaridade com elas e com suas tarefas.

Também na Enciclopédia, no § 19 Z (1995a, p. 65 [TN] [8/69]), consta:

Aqui, então, não é modéstia que impede o conhecimento e o estudo da verdade, porém a conviç̧ão de que já se possui a verdade em si e para si. Sem dúvida, os mais velhos [Älteren] põem agora sua esperança na juventude [ihre Hoffnung auf die Jugend], pois ela deve levar adiante o mundo e a ciência. Mas essa esperança apenas é posta na juventude [diese Hoffnung wird nur auf die Jugend gesetzt], na medida em que ela não permanece como está [sie nicht bleibt, wie sie ist], porém empreende o amargo trabalho do espírito [sondern die saure Arbeit des Geistes übernimmt].

Nos Escritos de Berlim, ao falar "Sobre a Lei de Reforma [Eleitoral] Inglesa", fala da "esperança de economizar na administração [Hoffnung zu Ersparnissen in der Verwaltung]", como um aspecto da então "esperança popular [populäre Hoffnung]" ([TN] [11/91]).

Nos Escritos de Nuremberg e Heidelberg, no "Discurso ao antecessor Reitor Schenk de 10.07.1809" ([TN] [4/306]), fala de "tempos de noções cheias de esperança de mundo e vida [Zeiten der Hoffnungsvollen Ahnungen von Welt und Leben], que são também o tempo de aprendizagem, que preparam para o mundo e a vida e nos conduzem neles"; depois disso, no "Discurso de final de ano letivo de 02.09.1811" ([TN] [4/344]), como já citamos, Hegel fala "encontrar uma causa e uma esperança de fazer algo de bom [eine Hoffnung hat, etwas Gutes zu bewirken]"; já no "Discurso de final de ano letivo de 02.09.1813" ([TN] [4/362]), Hegel fala de "estímulo [Sporn] para que eles [alunos] sejam melhores em seus estudos e recompensem melhor as esperanças de seus pais [die Hoffnungen ihrer Eltern] e os esforços de seus professores com eles"; por fim, ao falar das "negociações na assembleia dos estados do Reino de Württemberg", de 1815-1816 ([TN] [4/477-478]), fala-se da "esperança de uma contínua e maior ação e eficácia na vida política do Estado [Hoffnung eines dereinstigen weiteren Wirkens dazu und einer Wirksamkeit im politischen Leben des Staats]".

Além disso, nas Lições sobre a Estética, fala-se de todo um "mundo de esperanças e planos [Welt der Hoffnungen und Pläne]" ([TN] [13/398]) e, inclusive, citando Shakespeare, de que ""hoje brotam as suaves flores da esperança [heute sprossen die zarten Blüten der Hoffnung]"' ([TN] [13/538-539]). Por fim, convém citar ainda que, nas Lições sobre a História da Filosofia, fala-se de "esperança de um futuro [Hoffnung einer Zukunft]" ([TN] [19/409]) e, nos Escritos de Iena, fala-se até de "uma esperança de um futuro melhor [eine Hoffnung auf bessere Zukunft]" ([TN] [2/486]). Enfim, são várias ocorrências de "esperança" (Hoffnung) na Hegel Werke, registrando e destacando o seu uso por Hegel. 


\section{ConsideraÇões Finais}

Apresentados e analisados os diversos dados sobre conceito de "esperança" (Hoffnung) na Filosofia de Hegel, em relação ainda principalmente com os conceitos de "desesperança" (Hoffnungslosigkeit), de "temor" (Furcht), de "desespero" (Verzweiflung) e de "suicídio" (Selbsttötung - Selbstmord), vemos alguns aspectos questionáveis, mas também vários aspectos atuais e pertinentes. Destaca-se, sobretudo, o problema de "perder a esperança [die Hoffnung... verlieren]", de viver "sem esperança [ohne Hoffnung]", na "desesperança [ou na falta de esperança] [Hoffnungslosigkeit], podendo levar até ao "Verzweiflung [desespero]", inclusive ao suicídio. Ainda, destaca-se a busca e a defesa, por Hegel, de uma "esperança verdadeira [wahrhafte Hoffnung]", questionando as "esperanças iludidas [getäuschte Hoffnungen]", as "esperanças infundadas [ungegründete Hoffnungen]", as "esperanças vãs [vergeblichen Hoffnungen]", etc. Trata-se de procurar ou saber a resposta para a pergunta: "O que eu posso [ou o que me é permitido] [darf] esperar? [Was darf ich hoffen?]", certamente umas das questões fundamentais de nossa vida.

Em suma, o conceito de Hegel de "esperança" (Hoffnung) é importante e com vários aspectos atuais para compreender melhor nossa atualidade. Conhecer mais e melhor esse pensador moderno, certamente permite trazer para a contemporaneidade mais luzes, que nos guiem a encontrar os melhores caminhos para tentar impedir, ao máximo, por exemplo, o suicídio, promovendo muito mais a "vida" (Leben) e um "mundo de esperanças" (Welt der Hoffnungen), um mundo de "esperança de um futuro melhor" (Hoffnung auf bessere Zukunft).

\section{REFERÊNCIAS}

BOURGEOIS, Bernard. Hegel a Francfort ou Judaïsme-Christianisme-Hegelianisme. Paris: Vrin, 1970.

CROCE, Benedetto. O que é vivo e o que é morto na filosofia de Hegel. Trad. de Vitorino Nemésio. Coimbra: Imprensa da Universidade, 1993.

HEGEL, Georg Wilhelm Friedrich. Briefe von und an Hegel. Volume 2 - 1813-1822. Johannes Hoffmeister (Org.). Hamburg: Felix Meiner, 1953.

HEGEL, Georg Wilhelm Friedrich. Ciência da Lógica: 1. A Doutrina do Ser. Trad. de Cristian G. Iber et al. Petrópolis, RJ: Vozes; Bragança Paulista, SP: EDUSF, 2016.

HEGEL, Georg Wilhelm Friedrich. Enciclopédia das Ciências Filosóficas em Compêndio (1830): I - A Ciência da Lógica. Trad. de Paulo Meneses. São Paulo: Loyola, 1995a.

HEGEL, Georg Wilhelm Friedrich. Enciclopédia das Ciências Filosóficas em Compêndio (1830): III - A Filosofia do Espirito. Trad. de Paulo Meneses. São Paulo: Loyola, 1995b.

HEGEL, Georg Wilhelm Friedrich. Fenomenologia do Espírito. Trad. de Paulo Meneses. Vol. único - 7 a ed. rev. Petrópolis: Vozes - Bragança Paulista: USP, 2002.

HEGEL, Georg Wilhelm Friedrich. Filosofia do Direito (Linhas Fundamentais da Filosofia do Direito ou Direito Natural e Ciência do Estado em Compêndio). Tradução, notas, glossário e bibliografia de Paulo Meneses et. all. Recife: UNICAP; São Paulo: Loyola; São Leopoldo: UNISINOS, 2010.

HEGEL, Georg Wilhelm Friedrich. Hegel Werke. Berlin: Hegel-Institut, Talpa Verlag, 2000b.

HEGEL, Georg Wilhelm Friedrich. Cursos de Estética - Volume I. Trad. de Marco Aurélio Werle. $2^{\mathrm{a}}$ ed. rev. São Paulo: Editora da Universidade de São Paulo, 2001.

HEGEL, Georg Wilhelm Friedrich. Cursos de Estética - Volume II. Trad. de Marco Aurélio Werle e Oliver Tolle. São Paulo: Editora da Universidade de São Paulo, 2000.

INWOOD, Michael. A Hegel Dictionary. Oxford: Blackwell Publishing, 2007.

INWOOD, Michael. Dicionário Hegel. Trad. de Álvaro Cabral. Rio de Janeiro: Zahar, 1997.

JAPIASSÚ, Hilton; MARCONDES, Danilo. Dicionário Básico de Filosofia. $5^{\text {a }}$ Edição. Rio de Janeiro: Jorge Zahar Ed., 2008.

KONZEN, Paulo Roberto. O Conceito de Liberdade de Imprensa ou de Liberdade da Comunicação Pública na Filosofia do Direito de G. W. F. Hegel. Porto Alegre, RS: Editora Fi, 2013.

MENESES, Paulo. O desafio de traduzir Hegel para o português. In: IHU on-line. Edição 217, de 30.04.2007. São Leopoldo: UNISINOS, 2007.

MENESES, Paulo. Os horizontes da esperança. In: Síntese, Belo Horizonte, v. 27, n. 87, p. 113-122, 2000.

MÜLLER, Marcos Lutz. "A gênese conceitual do Estado ético". In: Revista Filosofia Política - Nova Série 2. São Paulo: L\&PM, p. 9-38, Abril de 1998.

PERTILLE, José Pinheiro. Faculdade do espírito e riqueza material: face e verso do conceito de Vermögen 
na filosofia de Hegel. Porto Alegre, 2005 (Tese - PPG Filosofia - UFRGS).

VAZ, Henrique C. de Lima. Por que ler Hegel hoje? In: BONI, Luis A. de (Org.). Finitude e Transcendência - Festschrift em homenagem a Ernildo J. Stein. Petrópolis: Vozes; Porto Alegre: EDIPUCRS, 1995. p. 222-242.

\section{NOTAS}

1 Cf. Vaz (1995, p. 225): “[...] sobre o fundamento assegurado da leitura filológica [ou do trabalho crítico-filológico] e da leitura histórica, podemos tentar nos situar no nível da leitura hermenêutica [ou da interpretação crítica] para buscar aí as razões que comprovem, para nós, a atualidade do texto hegeliano". Afinal, "a primeira condição para nos resolvermos a receber ou refutar as doutrinas que Hegel propõe é (sou por demais obrigado a recordar coisas que pareciam dever subentender-se) ler os seus livros: acabando com o espetáculo, entre cômico e triste, de acusar e injuriar um filósofo, que não se conhece" (CROCE, 1993, p. 188).

2 Todas as citações de textos de Hegel, usando as traduções em português publicadas, foram sempre comparadas com o texto original alemão da Hegel Werke (2000), o qual, infelizmente, por questão de espaço, não citaremos. Nas citações dos textos hegelianos sempre consta a referência, primeiro, do número do volume (Band) e, depois, da página (Seite) de Hegel Werke, mantendo os grifos em itálico do autor. O parágrafo (§) seguido da letra A indica Anmerkung (anotação) e o da letra Z designa Zusatz (adendo) ao caput. $O$ texto aqui traduzido ou com tradução alterada, seja de Hegel ou de outros autores, consta com a especificação de $[\mathrm{TN}]=$ Tradução Nossa. Além disso, haverá acréscimo de termos em alemão nas citações, com o fim de destacá-los e/ou mostrar alterações na tradução publicada (termos citados sempre mantendo o itálico ou não da versão original e entre colchetes [ ] ).

3 Cf. Japiassú e Marcondes (2008, p. 31): “O princípio fundamental de sua filosofia [de Bloch] é a esperança (Hoffnung)". Sobre isso, ver BLOCH, Ernst. O Princípio Esperança [Das Prinzip Hoffnung]. Vol. I, II e III. Rio de Janeiro: Contraponto/UERJ, 2005-2006. Obra de quase 1700 páginas: "uma enciclopédia da esperança", com as questões: "Quem somos? De onde viemos? Para onde vamos? Que esperamos? O que nos espera?".

4 O conceito de "liberdade" (Freiheit) é considerado o conceito-chave, meta-tema ou tema central da Filosofia de Hegel. Segundo Bourgeois (1970, p. 9 [TN]), "o tema fundamental e constante da reflexão hegeliana é a questão da liberdade"; conforme Pertille (2005, p. 114): "Em todas essas dimensões da definição hegeliana de espírito, está sempre presente a preocupação no estabelecimento das condições para tornar efetiva a própria liberdade. Aliás, esse é um meta-tema da filosofia hegeliana, isto é, um problema que lhe percorre transversalmente: pensar os requisitos não apenas para uma correta definição do conceito de liberdade, mas, sobretudo, indicando as condições para sua efetivação". Também Meneses (2007, p. 49) afirma: "o tema central da Fenomenologia é a liberdade (como aliás do resto da obra de Hegel)". Igualmente, Müller (1998, p. 79) reitera que a "liberdade é um tema que perpassa todo o sistema de Hegel e plasma decisivamente as etapas de sua formação, [...] ela se torna um dos motivos onipresentes e, mesmo, tema central".

5 Etimologia de esperança em: alemão: Hoffnung; latim: spes, sperare; grego: $\varepsilon \lambda \pi i ́ \delta \alpha$; inglês: hope; francês: espoir, espérance; italiano: speranza; espanhol: esperanza.

6 Cf. Japiassú e Marcondes (2008, p. 70): "Desespero (de des-: que indica o afastamento, e do lat. sperare: esperar) estado daquele que perdeu toda esperança, nada apostando no futuro $[\ldots] "$.

$7 \mathrm{Na}$ Fenomenologia do Espírito consta: “[...] quando o rigor do conceito [Begriffs] tiver penetrado na profundeza da coisa, então tal conhecimento e apreciação terão na conversa o lugar que lhes corresponde. A verdadeira figura [wahre Gestalt], em que a verdade [Wahrheit] existe, somente pode ser o sistema científico [wissenschaftliche System]. Colaborar [mitzuarbeiten] para que a filosofia [Philosophie] se aproxime da forma de 
ciência [Form der Wissenschaft] - da meta [Ziele] em que deixe [apenas] de chamar-se amor ao saber [Liebe zum Wissen] para ser saber efetivo [wirkliches Wissen] - é isto o que me proponho. Reside na sua natureza [Natur] a necessidade interior de que o saber [das Wissen] seja ciência [Wissenschaft]. [...] Chegou o tempo da elevação da filosofia à condição de ciência [die Erhebung der Philosophie zur Wissenschaft]" (HEGEL, 2003, p. 27-28 [TN] [3/14]). Também "[...] é particularmente necessário fazer de novo [wieder] do filosofar [Philosophieren] uma atividade séria [ernsthaftes Geschäft]. Para se ter qualquer ciência, arte, habilidade, ofício, prevalece a convicção da necessidade de um esforço complexo de aprendê-las e de exercitá-las. Ao contrário, no que toca à filosofia [Philosophie], domina hoje o preconceito de que qualquer um sabe imediatamente filosofar [philosophieren] e julgar a filosofia [...]" (HEGEL, 2002, p. 67 [TN] [3/62]). Também na Ciência da Lógica, Hegel afirma: "O ponto de vista essencial é que se trata em geral de um conceito novo do tratamento científico [wissenschaftlicher Behandlung]. Como lembrei em outro lugar* [Fenomenologia do Espírito], a filosofia [Philosophie], na medida em que deve ser ciência [Wissenschaft sein soll], não pode tomar de empréstimo para isso o seu método de uma ciência subordinada [untergeordneten Wissenschaft], [...], bem como tampouco pode contentar-se com garantias categóricas de uma intuição interior ou servir-se de arrazoamentos [Räsonnements] a partir da reflexão exterior." (HEGEL, 2016, p. 27-28 [TN] [5/16]).

8 Nas Lições sobre a História da Filosofia ([TN] [18/549]), ao falar de Hegesias de Cirene (c. 290 a.C.) e seus questionamentos, consta o seguinte: “[...] é como perguntar agora: O que eu posso saber? [Was kann ich wissen?] O que eu devo crer? [Was soll ich glauben?] O que eu posso esperar? [Was darf ich hoffen?] [...]".

9 Cf. Carvalho (1974, p. 6), nele consta "a fé ardente e comunicativa de Hegel no valor e no destino da filosofia".

10 Ainda consta ([TN] [18/11-12]): “[...] Mas, a miséria do tempo [Not der Zeit], que eu já mencionei, e o interesse dos grandes eventos mundiais, impediram também uma consideração fundamentada e séria [eine gründliche und ernste Beschäftigung] da filosofia [Philosophie] entre nós e dela afastaram uma atenção universal [eine allgemeinere Aufmerksamkeit]. Disso decorreu que, na medida em que naturezas sólidas se voltaram para a prática, planicidade e superficialidade [Flachheit und Seichtigkeit] tomaram posse da grande palavra na filosofia e se propagaram. Pode dizer-se certamente que, desde que a filosofia começou a surgir na Alemanha, nunca foi tão ruim [so schlecht] essa ciência [diese Wissenschaft] como exatamente no tempo presente [als gerade zu jetziger Zeit], nunca a vacuidade e a presunção [die Leerheit und der Dünkel] flutuaram tanto na superficie e com tal arrogância [Anmaßung] na ciência considerou e agiu como se tivesse o domínio em suas mãos. Para combater [entgegenzuarbeiten] essa superficialidade [Seichtigkeit], [...] e para tirar [hervorzuziehen] a filosofia da solidão [die Philosophie aus der Einsamkeit] em que mergulhou, podemos considerar que estamos sendo chamados [aufgefordert] pelo espírito do tempo mais profundo [von dem tieferen Geiste der Zeit]. [...]"'

11 Sobre isso, Moltmann (2005, p. 37-41) afirma: "Se a fé, para ser viva, depende da esperança, então o pecado da descrença evidentemente é sustentado pela desesperança. Geralmente, diz-se que o pecado tem origem no fato de o ser humano querer ser como Deus. Mas isso é apenas um aspecto do pecado. O outro aspecto dessa soberba é a falta de esperança [...]. Joseph Pieper mostrou, em seu tratado Über die Hoffnung [Sobre a esperança] (1949), com rara felicidade como essa desesperança pode tomar duas formas: ela pode ser presunção (praesumptio), mas pode transformar-se também em desespero (desperatio). Ambas são formas do pecado contra a esperança. A presunção é uma antecipação inoportuna, arbitrária, do cumprimento daquilo que se espera de Deus; o desespero é a antecipação inoportuna, arbitrária, do não cumprimento do que se espera de Deus. Ambas as formas de desesperança, tanto a antecipação do cumprimento como a renúncia à esperança, destroem o caráter peregrino, de estar a caminho, da esperança. Eles se revoltam contra a paciência da esperança, que confia no Deus da promessa. Impacientes, querem "já agora" o cumprimento, ou então "nunca mais" têm esperança. [...] A esperança 
e o pensamento que a ela corresponde não podem, portanto, receber a pecha de utopia, pois não se orientam para aquilo que é "sem lugar", mas para aquilo "que ainda não tem lugar" e que pode vir a tê-lo."

12 "Nunca nos atemos ao presente; apropriamo-nos antecipadamente do futuro, como se ele viesse muito devagar, como se quiséssemos acelerar-lhe o passo; lembramo-nos do passado, como para segurá-lo, já que desaparece muito depressa. Que insensatez errar pelos tempos que não são nossos e esquecer o único que nos pertence; que vaidade correr atrás dos que não existem e perder o único que tem existência. [...] Raras vezes pensamos no presente, e se pensamos nele só o fazemos para acender a luz de que queremos dispor no futuro. Nunca o presente é meta; passado e presente são meios, o futuro somente é a nossa meta. Assim nunca vivemos, mas esperamos viver; e assim é inevitável que nós, prontos sempre a ser felizes, nunca o somos." ([PASCAL,] Pensamentos, $\mathrm{n}^{\mathrm{o}} 172$ ).

13 A expressão "o eterno, que está presente [das Ewige, das gegenwärtig ist]" está no Prefácio da Filosofia do Direito e, assim, não seria do jovem Hegel, mas do Hegel adulto, de $1820 / 1821$.

14 Convém registrar que a tradução das três questões de Immanuel Kant, na Crítica da Razão Pura (KrV, B 833), é normalmente a seguinte: Was kann ich wissen? (O que posso saber?); Was soll ich tun? (O que devo fazer?) e, ainda, Was darf ich hoffen? (O que me é permitido esperar? [Mas, também, é traduzida por: O que posso esperar?]).

15 Sobre isso, ver Konzen (2017): O Conceito de Amor Ético na Filosofia do Direito de G. W. F. Hegel.

16 A tradução de Furcht é, normalmente, por "temor" (que usamos), mas, às vezes, é traduzida por "medo". Ora, Meneses, por exemplo, no mesmo § da Fenomenologia (2003), traduziu "Furcht zu irren" por "temor de errar" e, após, "Furcht vor dem Irrtume" por "medo do erro" (p. 72 [3/69-70]); ainda: "sentiu o medo da morte, do senhor absoluto [hat die Furcht des Todes, des absoluten Herrn, empfunden]" (p. 149 [3/152]) e, depois, "sentiram o temor de seu senhor absoluto - a morte [die Furcht ihres absoluten Herrn, des Todes, empfunden]" (p. 407 [3/438]).

17 Na Filosofia do Direito, Furcht ainda ocorre no § 258 A: "do temor ou da confiança [aus Furcht oder Zutrauen]"; e no $\S 324$ : "sua liberdade morreu no temor de morrer [ihre Freiheit ist gestorben an der Furcht zu sterben]".

18 Não é pretensão aqui apresentar a teoria dos sentimentos de Hegel, mas, nos $\S \S 471$ a 472, consta sobre o chamado "sentimento prático" (praktische Gefühl), afirmando, no § 472, que há o "sentimento totalmente subjetivo e superficial, do agradável ou desagradável"; depois, no § 472 A, consta: "Prazer, alegria, dor etc. [Vergnügen, Freude, Schmerz usf.], vergonha, remorso, satisfação etc. [Scham, Reue, Zufriedenheit usw.] são, por uma parte, somente modificações do sentimento prático formal, de modo geral; mas por outra parte são diversos por seu conteúdo, que constitui a determinidade do dever-ser." Já no $\S 472$ Z, consta: "O sentimento prático recebe, no entanto, ainda outras determinações [...]." No caso, primeiro, cita como "segundo lugar", os sentimentos que, "por seu conteúdo provir da intuição ou da representação - excedem em determinidade o sentimento do agradável ou desagradável", os quais, como citado, são "o prazer, a alegria, a esperança, o medo [ou o temor], a angústia, a dor etc." (das Vergnügen, die Freude, die Hoffnung, die Furcht, die Angst, der Schmerz usw.), citando na explicação ainda os sentimentos de "satisfação" (Zufriedenheit), de "contentamento" (Heiterkeit) e de "pavor" [ou terror] (Schrecken). A "terceira espécie de sentimento" (dritte Art von Gefühlen) é a que "nasce por ser também acolhido na vontade que-sente o conteúdo substancial, que deriva do pensar: [o conteúdo] do jurídico, moral, ético e religioso"; são "sentimentos que se diferenciam uns dos outros por seu conteúdo peculiar; e por ele obtêm sua justificação. A essa classe pertencem a vergonha [Scham] e o remorso [Reue]; pois ambos, em regra geral, têm uma base ética."

19 Convém destacar a tradução de Angst por angústia e Schrecken por pavor [ou terror], distinguindo-as de Furcht.

20 "Temor [Furcht]" em relação gradativa com "angústia [Angst]", "preocupação [Besorgnis]" e "terror [Schreck]".

21 Além disso, nas Lições sobre a História da Filosofia ([TN] [19/103]), citando Platão, consta: 
"Esta imagem mortal contém as paixões dominadoras e necessárias [...]: prazer [Vergnügen], sofrimento [Leid] (tristeza [Traurigkeit]), coragem [Mut], temor [Furcht], raiva [Zorn], esperança [Hoffnung], etc. Todos estes sentimentos [Empfindungen] pertencem à alma mortal."

22 Sobre isso, no Prefácio da Filosofia do Direito, depois de afirmar que era necessário "arrancar [herauszureißen] a filosofia [Philosophie] da vergonhosa decadência [schmählichen Verfall], em que ela mergulhou em seu tempo [in unseren Zeiten]" (2010, p. 32 [TN] [7/12]), Hegel afirmou o seguinte: "Assim como a razão não se contenta com a aproximação, enquanto essa não é nem fria nem quente e, por isso, vem a ser vomitada, tampouco se contenta com o frio desespero [kalten Verzweiflung] que admite que, nessa temporalidade, as coisas vão bastante mal ou, quando muito, mediocremente [...]." (2010, p. 44 [7/27]). Além disso, no $\S 21$ A, da Filosofia do Direito (2010, p. 68 [7/72-73]), afirma-se: "Os que falam filosoficamente de direito, moralidade, eticidade, e nisso querem excluir o pensamento e remetem ao sentimento, ao coração, ao ardor, ao entusiasmo, exprimem com isso o mais profundo desprezo em que caíram o pensamento e a ciência, uma vez que assim a própria ciência, mergulhada no desespero de si e na suprema debilidade [über sich in Verzweiflung und in die höchste Mattigkeit versunken], toma por princípio a barbárie e a ausência de pensamento, e no que dependesse dela, despojaria o ser humano de toda verdade, de todo valor e de toda dignidade." Sobre isso, convém destacar parte da carta de 30.10.1819 que Hegel escreveu para Georg Friedrich Creuzer (1771-1858): "Sobre nosso ensino, eu não preciso dizer nada, pois vós conheceis nossos estudiosos. A agitação política da Burschenschaft, o friesianismo de [Wilhelm] De Wette certamente em nada favoreceram a Universidade. [...] Nossas demais medidas políticas e de censura, vós as conheceis [...] - Que, aliás, tudo isso não contribui para elevar a serenidade da disposição, entende-se bem também junto a vós. - Eu estarei logo com 50 anos, passei 30 deles nestes eternos tempos inquietos de temer e de esperar [ewig unruhvollen Zeiten des Fürchtens und Hoffens], e esperava [hoffte] uma vez o fim do temer e do esperar [Fürchten und Hoffen]. [Agora] eu preciso ver que isso sempre continua, e sim, nas horas sombrias, pensa-se que se torna sempre pior." (1953, p. 218219 [TN]). Enfim, destaca-se a crítica contundente de Hegel à teoria de Jakob Friedrich Fries (1773-1843), por ser o "comandante supremo dessa superficialidade, que se chama filosofar" (2010, p. 36 [7/18]), o qual teria até promovido a então "agitação política da Burschenschaft".

23 Nos Escritos de Nuremberg e Heidelberg, no $§ 153$ ([TN] [4/50]), consta sobre "demência [Verrücktheit]" e suas "modificações diversas como loucura, delírio, frenesi, etc. [verschiedene Modifikationen wie Narrheit, Wahnsinn, Raserei usf.]". Sobre isso, convém ver também o $\S 408, \S 408 \mathrm{~A}$ e $\S 408 \mathrm{Z}$ da Enciclopédia, em que também se fala dessa doença [dieser Krankheit], afirmando, por exemplo, no § 408 A, que "ela [demência] é uma doença do psíquico, inseparável do corporal e do espiritual [ist sie \{Verrücktheit\} eine Krankheit des Psychischen, ungetrennt des Leiblichen und Geistigen]" (1995, p. 148 $[\mathrm{TN}][10 / 161])$.

24 Nos Escritos de Iena, mais precisamente nos "Aforismos de Hegels Wastebook" ([TN] [2/563]), consta: “[...] Deus se sacrifica, se entrega à aniquilação. Deus mesmo está morto [Gott selbst ist tot]; o supremo desespero [die höchste Verzweiflung] do abandono total de Deus [der völligen Gottverlassenheit]".

25 Não especificaremos aqui o local [e a circunstância] de publicação, pois o que importa é a questão do(s) adjetivo(s). Mas, pelo volume da Hegel Werke é possível ver qual é o texto hegeliano.

26 Na Ciência da Lógica consta: "O espanto insosso, no qual eles [astrônomos] se abandonam, as esperanças insípidas [ou banais] [abgeschmackten Hoffnungen] de viajar de uma estrela para outra, mesmo que apenas em uma outra vida, e de adquirir novos conhecimentos semelhantes [...]" (2016, p. 246 [TN] [5/266]) e, ainda, consta: “[...] se torna ilusória [getäuscht] a esperança de obter [Hoffnung ... zu erhalten], a partir desse princípio que deve ser mais profundo, uma explicação sobre o que é mais importante [...]" (2016, p. 390 $[5 / 430])$. 
27 Sobre isso, nos Primeiros Escritos, consta: “[...] o amor é mais forte do que o temor [die Liebe ist stärker als die Furcht]; ele [o amor] não teme o seu temor [sie fürchtet ihre Furcht nicht] [...]. [...] ele [o amor] tenta ver se a esperança não o ilude [ou engana] [ob die Hoffnung sie nicht getäuscht] [...]” ([TN] [1/247-248]). 